\title{
Monikielisyyttä ja muuttoliikkeen jälkiä
}

\author{
Aika- ja kielikerrostumat \\ Varkauden hautausmaiden nimimaisemissa
}

\section{Johdanto $^{1}$}

O. A. Kallion (1911) selvityksessä Savon maaseurakuntien sukunimistä kaupunkien sukunimet on rajattu ulkopuolelle, koska Kallion mukaan kaupunkinimistö muodostaa muuttoliikkeen vuoksi "sekalaisen seurakunnan". Tämä artikkeli tutkii tätä sekalaista seurakuntaa yhden suomalaisen kaupungin, Varkauden, sukunimien kautta. Keskitymme sukunimiä runsaasti sisältävään hautausmaamaisemaan ja lähestymme hautausmaiden sukunimiä kielimaisema- ja nimistöntutkimuksen näkökulmia yhdistellen.

Hautausmaita on tutkittu kielimaisemina aikaisemmin erityisesti Yhdysvalloissa. Vainajien nimiä ei kuitenkaan ole tutkittu, vaikka ne muodostavat hautausmaan visuaalisesti dominoivimman osan. Hautausmaakielimaisemaa voidaankin luonnehtia nimimaisemaksi, mutta millaisen nimimaiseman vainajien nimet muodostavat? Mitä kieltä henkilönnimet ovat, ja voiko niitä luokitella kielittäin? Mitä henkilönnimet kertovat paikkakunnasta, sen historiasta ja sen kehitykseen vaikuttaneista ihmisistä? Nämä ovat tämän kirjoituksen keskeiset tutkimuskysymykset, joita tarkastellaan Varkauden hautausmaiden nimimaisemassa.

Varkauden historiaa leimaa yhtäältä teollistuminen ja sen aiheuttama työperäinen muuttoliike paikkakunnalle, toisaalta yleinen suomalaisen yhteiskunnan kaupungistuminen muuttoliikkeineen. Vainajien hautamuistomerkit henkilönnimineen kertovat paikkakunnan menneisyydestä ja sen kehitykseen vaikuttaneista ihmisistä. Tavoitteemme on selvittää, millaisia jälkiä muuttoliikkeen kyllästämä historia on jättänyt varkautelaiseen

1 Kiitämme Sananjalan arvioijia arvokkaasta palautteesta artikkelin aiempaan versioon. Erityiskiitos kuuluu FT Sirkka Paikkalalle, joka on tarjonnut tukeaan lukuisissa yksityiskohdissa. FT Pirjo Mikkosta kiitämme avusta sukunimien analyysissä. Kiitämme yhteistyöstä myös Varkauden ev.-lut. seurakunnan seurakuntapuutarhuri Seija Kotilaista, toimistosihteeri Merja Määttää ja Varkaus-opas Katriina Niemistä, jotka ovat auttaneet aineistoa ja Varkauden historiaa koskevissa kysymyksissä. 
hautausmaanimimaisemaan. Artikkeli on osa käynnissä olevaa tutkimuskokonaisuutta, jossa tutkitaan suomalaisen teollisuuden kieli- ja kulttuurivaikutuksia.

Toinen tavoitteemme on osoittaa Varkauden aineiston kautta, että henkilönnimiä voi lähestyä nimistöntutkimuksen lisäksi kielimaisematutkimuksen näkökulmasta. Artikkeli laajentaa kielimaisematutkimuksen käsityksiä maisemassa näkyvistä erisnimistä henkilönnimiin, sillä tähänastinen kielimaisematutkimus on keskittynyt julkishallinnon rakennusten nimiin, kadun- ja paikannimiin sekä tuote- ja yritysnimiin. Rajaamme tarkastelun vainajien sukunimiin. Koska sukunimi on periytyvä ja heijastaa syntyhistoriaansa sekä osin myös syntypaikkaansa tai esiintymisaluettaan, se on avain tutkimuksessa, jossa ollaan kiinnostuneita muuttoliikkeen jättämistä jäljistä nimimaisemaan. Tarkastelun kohteena ovat sukunimimaisema ja sen kielet. Nimien kielet eivät kerro vainajien kielistä.

Artikkeli rakentuu seuraavasti: Luvussa 2 hahmottelemme kielimaisema- ja nimistöntutkimuksen risteyskohtia. Luku 3 esittelee Varkauden historiaa ja luku 4 aineiston eli tutkitut Varkauden hautausmaat. Luvussa 5 analysoimme Varkauden hautausmaiden sukunimien kieliä ja rakennetyyppejä kvantitatiivisesti. Luvussa 6 kuvataan sukunimien alueellista profiilia ja aikakerrostumia eri aikoina eläneiden vainajien nimissä. Viimeinen luku 7 luo tulkintoja ja kokoaa keskeisiä havaintoja yhteen.

\section{Kielet ja nimet maisemassa}

\subsection{Kielimaisematutkimus}

Kielimaisema (linguistic landscape) tarkoittaa kielten visuaalista läsnäoloa julkisissa tiloissa (Landry-Bourhis 1997). Kielimaisematutkimus kuvaa maisemassa näkyvien tekstien kautta alueen monikielisyyttä, yhteisön kieliä ja puhujien kielellisiä käytänteitä. Tutkimus on kohdistunut esimerkiksi kadun- ja paikannimikylttien, julkishallinnon kylttien, kaupallisten mainos- ja liikekylttien tai valotaulujen kirjoitukseen kielineen. Tarkasteltavana ovat usein kieli-ideologiset kysymykset yhteisön kielten ja niiden puhujien välisistä valtasuhteista, kontakteista ja konflikteistakin (ks. esim. Spolsky 2009). Painopiste on ollut urbaaneissa metropoleissa (ks. esim. Backhaus 2007), mutta myös perifeerisempien paikkojen, kuten pohjoisruotsalaisen Pajalan pikkukunnan, kielimaisemia on tutkittu (Alanen 2012).

Kielimaisemia on kuitenkin tutkittu jo ennen kuin Rodrique Landry ja Richard Bourhis (1997) lanseerasivat kielimaisema-käsitteen (ks. Spolsky 2009). Varhaisten kielimaisematutkimusten joukkoon voidaan lukea myös hautausmaiden monikielisyyttä koskevat tutkimukset, kuten Thomas Gravesin $(1983$; 1988) analyysi Pennsylvaniaan muuttaneiden saksalaisten hautausmaista. Myös uudemmassa hautausmaita koskevassa kielimaisematutkimuksessa tarkastellaan muuttoliikkeen jälkiä Yhdysvalloissa, missä on tutkittu hollantilaisten (VanDam 2007), tšekkiläisten (Eckert 1998) ja liettualaisten (Tamosiunaite 2012) maahanmuuttajien hautausmaita.

Hautausmaalla osan kielimaisemaa muodostavat vainajien nimet. Nimien rinnalla hautamuistomerkeissä esiintyy muita tekstejä, jotka kertovat ohikulkijoille esimerkiksi 
vainajan ammatista, muistomerkin pystyttäjästä tai jälkeen jääneistä omaisista. Aikaisemmissa tutkimuksissa kuvataan näitä hautamuistomerkkeihin kaiverrettuja tekstejä, joiden kieli- ja ortografiset valinnat kuvastavat omaisten keinoja ylläpitää vainajan ja omaa kielellis-etnistä identiteettiä tai assimiloitua ympäröivään kieliyhteisöön (ks. esim. Eckert 1998; Graves 1983; 1988). Varkauden vanhimpien hautausmaiden viisikielistä kielimaisemaa (suomi, ruotsi, saksa, venäjä ja latina) tarkastellaan Leena Kolehmaisen (tulossa) tutkimuksessa, jossa esiin nousee monikielisyyden lisäksi hautausmaan moniäänisyys: maisemaan tallentuneet kielet voivat omaisten ja vainajan lisäksi edustaa muitakin toimijoita, kuten muistomerkin valmistajaa tai kaivertajaa. Hautamuistomerkkeihin kaiverrettuja vainajien nimiä ei näissä aikaisemmissa tutkimuksissa kuitenkaan kuvata. Nimet eroavat hautamuistomerkkien muista teksteistä: ne eivät kerro vainajan tai kieliyhteisön kielestä tai kielistä, eikä vainajan nimen kaivertaminen hautamuistomerkkiin ole kielellinen valinta.

\subsection{Erisnimien kielet kielimaisematutkimuksessa}

Kielimaisematutkimuksen ytimessä on maisemassa näkyvän kirjoituksen kielen määrittäminen. Erisnimet ovat merkittävä osa maisemaa (Puzey 2016), mutta niiden kielen luokittelu on osoittautunut haasteelliseksi. Esimerkiksi kaupallisia nimiä, kuten Nike, Coca Cola tai Ford, on vaikea luokitella yksiselitteisesti mihinkään kieleen. Loulou Edelman (2009) luo katsauksen tutkijoiden keskenään erilaisiin ratkaisuihin: Osa tutkijoista luokittelee erisnimet kielen perusteella etymologisesti. Vaihtoehtoisesti erisnimet ymmärretään kielikohtaisiksi, koska niitä voi mukauttaa (esim. italian Venezia - ranskan Venise, Edelman 2010, 71) ja kääntää (esim. saamen Gáivuotna ja norjan Kåfjord, Puzey 2011; 2016). Toisen näkemyksen mukaan erisnimet eivät lukeudu mihinkään kieleen: koska erisnimet kielisukulaisuuden tai lainautumisen vuoksi voivat olla monen kielen yhteisiä ilmauksia, ne ovat joko kaikille kielille yhteisiä tai eivät kuulu vain yhteen yksittäiseen kieleen.

Myös tarkastelijan kieliresurssit vaikuttavat tulkintaan. Esimerkiksi Lovers on hollantilainen sukunimi, joka on otettu Amsterdamissa kanavaristeilyjä järjestävän yrityksen nimeksi. Vastaanottajasta riippuen tämä risteilyaluksissa näkyvä nimi on mahdollista tulkita joko hollannin- tai englanninkieliseksi. (Edelman 2010.) Kielimaisema ei olekaan yhtenäisesti koettu tila, vaan yksilöiden tulkinnat tilassa näkyvistä teksteistä vaihtelevat (ks. myös Tufi-Blackwood 2010, 199-200).

Meillä Suomessa maisemassa näkyviä henkilönnimiä tarkastellaan Väinö Syrjälän (2016) Karjaata ja Kauniaisia koskevassa kielimaisematutkimuksessa, jossa yritysten mainoskylttien sisältämät työntekijöiden nimet muodostavat yhden analysoitavan yksityiskohdan. Syrjälä seuraa Paula Sjöblomia (2006), jonka mukaan yritysnimissä henkilönnimet eivät kuulu mihinkään kieleen. Ne ovat kielettömiä tai kieleltään neutraaleja ilmauksia, eli ne eivät leimaudu mihinkään yksittäiseen kieleen, koska nimenantajan näkökulmasta oman nimen valinta yrityksen nimeksi ei ole kielen valintaa (esim. Raija Järvi Oy $L k v$ ). Osa yritysnimien henkilönnimistä voidaan kuitenkin luokitella kielen perusteella. Yritysnimissä esiintyvät henkilönnimet, jotka eivät viittaa omistajaan, ovat 
tiettyä kieltä: esimerkiksi Ptolomaeus $(\mathrm{O} y)$ ja Anaxagoras $(\mathrm{Oy})$ ovat latinaa ja kreikkaa. Nimet voivat olla monikielisiäkin. Esimerkiksi yritysnimessä Jokilaiva Cindy $(\mathrm{O} y)$ yhdistellään suomea ja englantia, joten se on inherentisti monikielinen. (Sjöblom 2006, 113, 115, 139.) Myös henkilönnimet voivat olla monikielisiä. Kaksi etunimeä (esim. Erkki Einar) tai etu- ja sukunimi (esim. Vegard Halonen) voivat muodostaa monikielisen eri kielten nimistä koostuvan kokonaisuuden ja indikoida henkilön kuulumista kahteen erikieliseen kulttuuriin (Saarelma-Paukkala 2017).

\subsection{Sukunimien kielet nimistöntutkimuksessa}

Terhi Ainiala, Minna Saarelma ja Paula Sjöblom (2008) luovat katsauksen suomalaiseen nimistöntutkimukseen, jossa sukunimen kieli on monitulkintainen käsite. Synkronisessa tutkimuksessa sukunimien kieltä lähestytään yleensä kielijärjestelmän näkökulmasta. Nimielementtien, sanojen ja johdinainesten kieli tai kielet ovat kriteerinä, kun sukunimiä luokitellaan kielen mukaan tai rajataan tutkimus tietynkielisiin sukunimiin. Suomenkielisen enemmistön ja kielivähemmistöjen, kuten suomenruotsalaisten, nimiä on tapana tarkastella toisistaan erillään ja erikielisinä järjestelminä. Esimerkiksi Marianne Blomqvist $(1993,186)$ toteaa:

Entydigt svenska är naturligtvis namn som bildats till ord eller element som är eller varit levande i svenskan.

Samoin suomenkielisen sukunimistön tutkimusperinteessä sukunimi on luokiteltu suomenkieliseksi, jos se on muodoltaan ja äänneasultaan suomenkielinen tai suomenkielistynyt. Keskeisiä kielivihjeitä ovat johdinainesten kieli (esim. -lA, -nen vs. -s, esim. Smeds), kantasanatyyppisten nimien sana-ainesten kieli (esim. Niemi vs. Berg) ja yhdyssanatyyppisten nimien rakenneosien kieli (esim. Koivumäki vs. Holmström). (Mikkonen-Paikkala 2000, 9; Paikkala-Paikkala 2000, 33-34.)

Kielten rajojen sumeus nousee esille myös nimistöntutkimuksessa. Läheisten sukukielten nimistössä kielen täsmällinen määrittäminen on vaikeaa, ja nimissä säilynyt vanha ortografiakin vaikeuttaa tulkintaa (Paikkala-Paikkala 2000, 33-34, Blomqvist 1993, 187, 214-220). Osa nimistä taas on syntyhistorialtaan monilähtöisiä: sama nimi on saattanut syntyä kahdessa eri paikassa eri lähtökohdista, mikä sekin vaikuttaa kielitulkintoihin. ${ }^{2}$ Esimerkiksi Sirkka Paikkala ja Jarmo Paikkala (2000) lukevat vierasnimiin eli ei-suomenkielisiin nimiin ruotsin- ja muunkielisten sukunimien lisäksi Suomessa syntyneet monikieliset nimet, joissa on yhdistelty suomen ja toisen kielen elementtejä (Lahnavik, HarjuJeanty). Toisaalta suomenkielisinä he pitävät esimerkiksi kotoperäisellä - $l A$-johtimella muodostettuja vierasperäisiä aineksia sisältäviä sukunimiä (Blommila). Muodoltaan ja äänneasultaan suomenkielisiksi tai suomalaistuneiksi tulkitaan Apelli, Bryggari ja Viikki,

2 Kiitämme FT Sirkka Paikkalaa huomion kiinnittämisestä tähän mahdollisuuteen. 
kun taas suomenkielisinä ei pidetä nimiä Arinén, Järvelin ja Kallaste niiden ei-suomenkielisen kirjoitusasun tai johtimen vuoksi. Vierasnimiä ovat heidän mukaansa myös Bunda, Keynäs ja Katona, koska niiden kieli jää epäselväksi. Koska aineisto on iso ja koskee koko väestöä, on luokittelu väistämättä karkeajakoinen. Esimerkiksi nimet, jotka samanasuisina kuuluvat useampaan kieleen (Lilja), on mahdollista laskea vain yhteen ryhmään. Paikkala ja Paikkala (2000, 33-34) lukevat ne yleensä suomenkielisiin. Blomqvist (1993, 187) puolestaan lukee vastaavat nimet ruotsinkielisiksi.

Luokittelueroja tuottavat myös latinan-, kreikan- ja ranskankielisiä vierasjohtimia sisältävät sukunimet (Arinén, Järvelin), jotka Paikkala ja Paikkala (200o) luokittelevat vierasnimiksi. Blomqvist $(1993,186,188,192)$ taas lukee nämä ruotsinkielisiksi: vaikka nimet on muodostettu vieraselementtejä hyödyntäen, muodostusmallista on tullut produktiivinen, eivätkä nimet enää hahmotu vierasnimiksi (Nylander, Sirén, Wegelius). Tulkinnanvaraisuutta tuottavat myös (ala-)saksasta lainatut ja ruotsiin vakiintuneet elementit (esim. -stedt), joilla muodostetut sukunimet Blomqvist $(1993,186)$ lukee ruotsinkielisiksi.

Nimistöntutkimuksessa sukunimien synkroninen kieliluokittelu on siten samalla tavalla haasteellista ja tutkimusasetelmasta riippuvaista kuin erisnimien luokittelu kielimaisematutkimuksessa. Tässä kirjoituksessa omaksumme näkemyksen, jonka mukaan sukunimiä voi luokitella kielittäin. Kielten luokittelu, jota havainnollistamme luvussa 5, yhdistelee kielimaisema- ja nimistöntutkimuksen näkökulmia.

\section{Varkaus sulatusuunina ja vastaanottokylänä}

Varkaus on itäsuomalainen väkiluvultaan hiipuva paikkakunta, jossa tämän artikkelin kirjoittamishetkellä asukkaita on noin 21 ooo. Väkiluvun kehitys on historiassa ollut kuitenkin toisenlainen. Tämä käy ilmi taulukosta 1, joka kuvaa Varkauden väkiluvun kehitystä 1850-luvulta nykypäivään. 1980-luvulle saakka jatkunut väestönkasvu ei aiheutunut syntyvyydestä, vaan sen pääasiallisena syynä olivat teollistuminen, talouselämän yleisten suhdanteiden mahdollistama teollisuuden kehittyminen, teollisuuden aiheuttama työperäinen muuttoliike muuttovoittoineen sekä kaupungistuminen (Soikkanen 1963, 283, 292-293; Nevala 2003, 27).

Taulukko 1. Varkauden väkiluku 1850-2017. Lähteet: Soikkanen (1963, 309-310), Tilastokeskus $(2017,2019)$.

\begin{tabular}{|c|c|c|c|c|c|c|c|}
\hline Vuosi & Väkiluku & Vuosi & Väkiluku & Vuosi & Väkiluku & Vuosi & Väkiluku \\
\hline 1850 & 1107 & 1910 & 3407 & 1970 & 26181 & 2017 & 21155 \\
\hline 1870 & 1578 & 1930 & 8548 & 1990 & 26428 & & \\
\hline 1890 & 2110 & 1950 & 17656 & 2010 & 22777 & & \\
\hline
\end{tabular}

Historian merkkipaalu on vuosi 1815, jolloin Varkauteen perustettiin rautaruukki. Ruukin ympärille kehittyi teollinen yhdyskunta, joka kasvoi ja itsenäistyi emopitäjistään 
Joroisista ja Leppävirrasta kauppalaksi 1929 ja kaupungiksi 1962. Teollisuuden ja työperäisen muuttoliikkeen lisäksi väkilukua kasvattivat 1930-luvulla alueliitokset ja -muutokset (Soikkanen 1963, 311). 2000-luvulla asukasluku on pienentynyt kuntaliitoksista huolimatta (ks. taulukko 1).

Taulukosta 1 käy ilmi muuttoliikkeen eri aikoina vaihdellut volyymi. 180o-luvulla työvoiman kysynnän ja väkiluvun lisääntyminen oli hidasta mutta 1900-luvulla kiihtyvää. Kun tehtaat siirtyivät Ahlströmin perheyhtiölle vuonna 1909, investoinnit vaativat nopeasti lisää työvoimaa. 1980-luvulla taas teollisuustyön yleinen rakenteellinen muutos alkoi pienentää väestönkasvua. Varkaudesta on toki muutettu myös pois, ja monet teollisuuden työtehtävät ja rakennustyöt ovat olleet määräaikaisia (Soikkanen 1963, 293-297).

Kaupungin teollisen syntyhistorian ja työperäisen muuttoliikkeen vuoksi varkautelaisista suuren osan juuret ovat alun perin muualla. Kaupunkia luonnehditaankin "sulatusuuniksi suomalaisessa mittakaavassa" (Soikkanen 1963, 298) ja "vastaanottokyläksi" (Itkonen 2004, 95). Muuttoliikkeen vaihteluita havainnollistaa taulukko 2. Varkauteen muutettiin 1800-luvulla ja 1900-luvun alussa erityisesti emopitäjistä Joroisista ja Leppävirralta sekä ympäröivän Itä-Suomen alueelta. 1910-luvulta lähtien Varkaus on vetänyt puoleensa väkeä yhä laajemmalta alueelta Itä-Suomesta ja muualta Suomesta. (Soikkanen 1963, 299-300.)

Taulukko 2. Varkauteen muuttaneiden lähtöpaikkakunnat 1866-1950. Taulukossa on osin uudelleen ryhmitelty ja yhdistelty Soikkasen $(1963,299)$ esittämiä tietoja.

\begin{tabular}{|c|c|c|c|c|}
\hline & Leppävirta & Joroinen & $\begin{array}{l}\text { Muu Kuopion ja } \\
\text { Mikkelin lääni (ml. } \\
\text { Pohjois-Karjala) }\end{array}$ & Muu Suomi \\
\hline $1866-1870$ & 29 & 20 & 26 & 38 \\
\hline $1871-1880$ & 216 & 113 & 141 & 137 \\
\hline $1881-1890$ & 115 & 23 & 89 & 110 \\
\hline $1891-1900$ & 126 & 50 & 108 & 73 \\
\hline $1901-1910$ & 218 & 88 & 176 & 111 \\
\hline $1911-1920$ & 201 & 109 & 556 & 659 \\
\hline $1921-1930$ & 606 & 276 & 809 & 600 \\
\hline $1931-1940$ & 1473 & 630 & 2719 & 2989 \\
\hline $1941-1950$ & 907 & 420 & 2155 & 4965 \\
\hline
\end{tabular}

Varkauteen tultiin sekä maaseudulta että kaupungeista. Tärkeimmät kaupungit olivat Helsinki ja Viipuri - jälkimmäisen rooli hiipui rajan sulkeuduttua. Helsingissä oli

3 Kuopion lääni kattaa Soikkasen (1963) historiassa Joensuun ympäristökuntineen. 
1800-luvulla ja 1900-luvun alussa tekniikan koulutusta, mikä selittää muuttoliikettä kaupungista. Liikenneyhteyksien ja -välineiden kehittyessä Varkauteen tultiin lopulta kaikkialta Suomesta. (Soikkanen 1963, 302-304.) Muuttoliikettä voi jäljittää myös kielitilastojen kautta. Niihin taltioidut ruotsinkielisten puhujien absoluuttiset määrät olivat korkeimmillaan 1960-luvulla, jonka jälkeen ruotsinkieliset ovat muuttaneet massoittain pois Varkaudesta. (Suomenmaan tilastollinen vuosikirja 1879-, Suomen tilastollinen vuosikirja 1910-1972 ja Tilastokeskus 2019.)

Ulkomailta Varkauteen siirtyneet eivät näy taulukossa 2. Näitä muuttajia on vain vähän, lähinnä Tukholmasta ja Pietarista. Tilastojen ulottumattomiin jäävät Saksasta teknisten investointien, kuten paperikoneiden, mukana saapuneet rakennus- ja käyttöönottomiehistöt mahdollisine perheineen. Useat 1920-luvulla rakennettujen paperikoneiden saksalaisista asentajista jäivät tehtaan palvelukseen Varkauteen, mutta joutuivat toisen maailmansodan puhjetessa palaamaan Saksaan asepalvelukseen. Osa heistä palasi sodan jälkeen Varkauteen. (Soikkanen 1963, 163, 304, 343.) Taulukosta puuttuvat myös 1800luvun puolivälissä Ruotsista ja emämaasta Venäjältä rekrytoidut ammattilaiset (ks. Ollikainen ym. 1979, 21).

\section{Varkauden vanhimmat hautausmaat}

Tutkimuksen aineisto muodostuu valokuvista, jotka on otettu Varkauden kahden van-

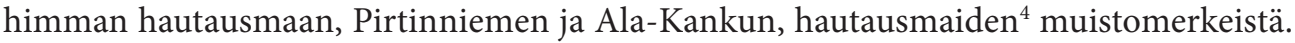
Vuosina 2009-2011 kuvattu aineisto on saatu tutkimuskäyttöön Varkauden evankelisluterilaiselta seurakunnalta. ${ }^{5}$ Taulukko 4 kokoaa yhteen numeerista tietoa aineistosta ja havainnollistaa hautausmaiden kokoeroja. Pirtinniemen ja Ala-Kankun sukunimiä ${ }^{6}$ tarkastellaan jatkossa maisema- eli hautausmaakohtaisesti erikseen. Tästä syystä taulukossa ei ilmoiteta molempien hautausmaiden erilaisten sukunimien yhteislaskettua lukumäärää.

4 Lisäksi Varkaudessa on neljä nuorempaa ja suurempaa hautausmaata. Aineisto ei siten muodosta kattavaa läpileikkausta Varkauden väestöön, jonka tutkimiseen tarvittaisiin toisenlaisia aineistoja. Pirtinniemen analyysi koskee hautausmaan ns. vanhaa osaa. Talvi- ja jatkosodassa menehtyneille perustettu sankarihautausmaa rajattiin tämän tutkimuksen ulkopuolelle.

5 Suomen Sukututkimusseuran hautausmaatietokannan valokuviin (http://haudat.genealogia.fi/php/ indexs.php) verrattuna Varkauden ev.-lut. seurakunnalta saamamme tutkimusaineiston etu on, että se sisältää useita valokuvia samasta hautamuistomerkistä. Tämä helpottaa tekstien tulkintaa. Käyttämiimme valokuviin on taltioitu myös naapurihaudat. Myös tällä on maiseman analyysin kannalta merkitystä (ks. esimerkiksi lukua $5 \cdot 3$ ja huomioita maiseman käännetyistä nimistä).

6 Tutkittujen Varkauden hautausmaiden vainajat ovat osin kuolleet ennen kuin ensimmäinen sukunimilaki tuli Suomessa voimaan vuonna 1921 (Laki sukunimestä N:o 328/1920). Kaikissa hautamuistomerkeissä ei siten ole varmuutta siitä, onko kyse henkilön suku- vai liikanimestä. Käytämme tässä artikkelissa selvyyden vuoksi termiä sukunimi kaikista nimistä riippumatta vainajien kuolinvuodesta. 
Taulukko 3. Tutkimusaineisto lukuina.

\begin{tabular}{|l|l|l|c|}
\hline & $\begin{array}{l}\text { Pirtinniemi } \\
(1864-)\end{array}$ & $\begin{array}{l}\text { Ala-Kankku } \\
(1888-)\end{array}$ & Yht. \\
\hline Valokuvia & 320 & 1122 & 1442 \\
\hline $\begin{array}{l}\text { Vainajien sukunimiä hautamuistomerkeissä } \\
\text { (eri sukunimiä/sukunimien esiintymiä) }\end{array}$ & $57 / 72$ & $221 / 528$ & $/ 600$ \\
\hline $\begin{array}{l}\text { Vainajien tyttönimiä hautamuistomerkeissä } \\
\text { (eri sukunimiä/sukunimien esiintymiä) }\end{array}$ & $5 / 5$ & $117 / 142$ & $/ 147$ \\
\hline
\end{tabular}

Pirtinniemen hautausmaa on Varkauden vanhin hautausmaa, joka on ollut käytössä 1700-luvulta saakka mutta perustettu virallisesti vuonna 1847 (Soikkanen 1963, 704). Se on vuonna 1865 perustetun Varkauden ruukinseurakunnan hautausmaa. Seurakunnan muodostivat aluksi läheinen Kosulanniemen tila ja Päiviönsaaren alue, jossa ruukin teollisuustuotanto ja palvelut toreineen, kievareineen, kouluineen ja kirkkoineen sijaitsivat. Valokuva-aineistossa Pirtinniemen vanhin hautamuistomerkki on vuodelta 1850 ja uusin vuodelta 2003. Historialliselle hautausmaalle ei enää myönnetä uusia hautapaikkoja (Kotilainen 2015). Taulukosta 3 käy ilmi, että hautamuistomerkeissä sukunimiä on yhteensä 72 ja erilaisia sukunimiä 57 . Vainajien tyttönimiä on 5 . Tyttönimiä ei ole laskettu mukaan sukunimien kokonaismääriin, vaan niitä tarkastellaan omana ryhmänä erikseen luvussa 5.3.

Ruukkiseurakunnan ulkopuolelle jäi mökkihökkeleissä Luttilan alueella asuva ruukin työ- ja loisväestö. Vuonna 1888 käyttöön otettu Ala-Kankun hautausmaa on perustettu heidän asuinalueensa läheisyyteen. (Soikkanen 1963, 701-702, 704-705.) Ala-Kankun valokuva-aineiston vanhin hautamuistomerkki on vuodelta 1891 ja uusin vuodelta 2010. Sukunimiä Ala-Kankun aineistossa on yhteensä 528, joista erilaisia sukunimiä on 221. Tyttönimiä on yhteensä 146, joista erilaisia tyttönimiä on 118. Ala-Kankkuun haudataan edelleen, mutta uusia hautapaikkoja myönnetään vain olemassa oleviin sukuhautoihin (Kotilainen 2015).

Hautausmaat eroavat profileiltaan. Pirtinniemi heijastaa ruukin vanhempaa historiaa, ja hautamuistomerkeistä päätellen sinne on haudattu oman aikansa nimekkäimpiä henkilöitä. Myös Ala-Kankkuun on haudattu teollisuuden ja elinkeinoelämän merkkihenkilöitä, mutta sijainti työläisten asuinalueella lyö sille erilaisen leiman.

Vanhimmat hautamuistomerkit ovat osin huonossa kunnossa, ja esimerkiksi puisten ristien ja hautalautojen maalattuja tekstejä on kulunut pois. Kaikkien hautamuistomerkkien kirjoituksista ei enää saa selvää. Kaikissa hautamuistomerkeissä ei ole vainajan sukunimeä vaan ainoastaan etunimi. Analyysissä mukana ovat hautamuistomerkit, joissa vainajan sukunimi on ilmoitettu ja joista se on luettavissa. Maisemassa näkyvät nimet eivät myöskään välttämättä ole vainajien nimiä. Hautamuistomerkkiin on voitu kaivertaa hautapaikan varanneen perheenjäsenen nimi, vaikka henkilö ei ole vielä menehtynyt. Hautoja ja hautamuistomerkkejä on ajan kuluessa hävinnyt ja poistettu käytöstä, ja vanhoja hautoja on otettu uudelleen käyttöön. Täsmällistä tietoa näistä ei kuitenkaan ole, kuten ei siitäkään, ovatko poistamiset ja uudelleen käyttöön ottamiset tapahtuneet 
väestöryhmittäin tasapuolisesti. Kuvattavana on siten nykyajan maisema sellaisena kuin se hautausmaavierailijalle on säilynyt.

Valokuva-aineiston sukunimet järjestettiin Access-tietokantaan. Nimien lisäksi mukaan kirjattiin vainajan elinaika, ja kukin sukunimi luokiteltiin kielen ja rakenteen perusteella. Tyttönimiä lukuun ottamatta sukunimet luokiteltiin myös alueellisen profiilinsa perusteella.

\section{Sukunimimaisemien kielet ja nimien rakennetyypit}

Kuvaamme seuraavassa Varkauden hautausmaiden nimimaisemia. Esittelemme ensin käyttämämme luokitteluperusteet (5.1), jonka jälkeen kuvaamme hautausmaakohtaisesti Pirtinniemen (5.2) ja Ala-Kankun (5.3) nimien kieliä ja rakennetyyppejä. Lopuksi analysoidaan maisemassa näkyviä tyttönimiä (5.4).

\subsection{Luokitteluperusteet}

Analysoimme sukunimien kielen kielimaisema- ja nimistöntutkimuksen näkökulmia yhdistellen: sukunimen kieli määritellään nimen rakenneosien, kantasanojen ja johdinainesten kielen perusteella. Nimet on jaoteltu suomen- ja ruotsinkielisiin, muunkielisiin ja monikielisiin nimiin. Luokittelu kuvaa nimenomaan maiseman nimien kieliä, jotka eivät kerro vainajien kielistä. Suomen- ja ruotsinkielisiä ovat nimet, joiden rakenneosat ovat suomea tai ruotsia (Varkaudessa esimerkiksi Itkonen ja Bergström). Muunkielisiin nimiin lukeutuvat nimet, jotka eivät ole suomea tai ruotsia. Varkauden aineistossa niitä ovat saksan- ja englanninkieliset nimet (esim. Wahl, Vright).

Monikielisillä nimillä tarkoitamme Sjöblomin (2006) tapaan nimiä, jotka rakentuvat kahden tai useamman kielen aineksista. Suurin osa monikielisistä nimistä on säätyjakoiseen nimijärjestelmään palautuvia oppineistonimiä (esim. Ålander). Oppineistonimet on muodostettu liittämällä suomen- tai ruotsinkieliseen kantasanaan latinan-, kreikantai ranskankielinen johdin. Nimet ovat syntyneet Suomessa, mutta ne eivät ole suomea eivätkä ruotsia. Nimen kantasana on alun perin viitannut nimenkantajan kotiseutuun, ammattiin tai aikaisempaan sukunimeen. Nimien kääntäminen suomesta tai ruotsista klassisille kielille oli myös yleistä. (Oppineistonimistä ks. esim. Tegnér 1930 [1882], 98-119; Modéer 1989, 122-125; Blomqvist 1993, 136-153, 150-151; Mikkonen-Paikkala 2000, 24-25; Paikkala 2004, 106.) Niiden kuvauksessa ei ole aikaisemmin käytetty monikielinen-termiä. Eero Kiviniemen, Ritva Liisa Pitkäsen ja Kurt Zilliacuksen termioppaassa (1974) monikielisiä eri kielten aineksista koostuvia erisnimiä kutsutaan sekanimiksi, joka ei mielestämme ole samalla tavalla neutraali kuin tässä kirjoituksessa suosimamme termi monikielinen nimi.

Lisäksi sukunimet on luokiteltu viiteen rakennetyyppiin: kantasanatyyppisiin, yhdyssanatyyppisiin, johtimellisiin, patronyymisiin ja aviollisiin kaksoisnimiin eli yhdistelmänimiin. Jako seuraa suomalaisessa nimistöntutkimuksessa yleisesti käytettyä luokittelua (esim. 
Paikkala-Paikkala 2000, 36-38). Se vastaa myös aineiston ei-suomenkielisten nimien tutkimuksen perinteitä (ks. esim. Blomqvist 1993, 180-181, 188; Seibicke 2008, 162-164). Eri nimityyppien yleisyydessä on luonnollisesti eroja eri kielten nimijärjestelmissä.

Kantasanatyyppiset nimet ovat johtimettomia nimiä (esim. Seppä, Sommar, Gerdt). Yhdyssanatyyppiset nimet muistuttavat yhdyssanoja, vaikkei niitä varsinaisina yhdyssanoina pidetäkään (esim. Karivalo, Nyström, Seseman). Johtimelliset nimet taas sisältävät suomessa tai jossain muussa kielessä esiintyvän johdinaineksen (esim. Rajala, Luostarinen, Brummer). Sukunimeä ei ole laskettu johtimelliseksi, jos nimi on muodostettu suoraan johtimellisesta yleiskielen sanasta (esim. Nuotio). Patronyymiset nimet ovat -sonpäätteisiä sukunimiä (esim. Larsson), jotka ovat kehittyneet 1800-1900-luvun vaihteessa patronyymisistä lisänimistä tai joita on otettu mallinmukaisesti ilman, että sisältönä olisi oman isän nimi (Paikkala 2004, 426, 546). Aviolliset kaksoisnimet ovat olleet mahdollisia vuonna 1929 säädetystä avioliittolaista alkaen (esim. Helve-Hirvonen).

Koska yksi tämän tutkimuksen lähtökohdista on kielimaisematutkimus, kaikki maiseman ortografialtaan erilaiset nimet on laskettu eri nimiksi (esim. Spåra/Spåre, Immonen/Immone, Jurvainen/Jurwainen). Pirtinniemessä tällaisia nimipareja on kaksi ja AlaKankussa viisi. Ratkaisu korostaa maiseman monimuotoisuutta, joka ei synny ainoastaan erilaisista nimistä, vaan variaatiota tuottavat myös kirjurien jäljet kirjoitusvirheineen ja oman aikansa ortografiset konventiot.

\subsection{Pirtinniemi}

Taulukko 4 kuvaa Pirtinniemen pienemmän ja vanhemman hautausmaan sukunimimaisemaa. Suomenkieliset sukunimiesiintymät muodostavat kolmanneksen kaikista hautausmaan sukunimistä, ruotsinkielisiä on hieman yli kolmasosa, ja kun myös muun- ja monikieliset sukunimet huomioidaan, maisemassa dominoivat ei-suomenkieliset nimet. Kaikki suomenkieliset nimet ovat johtimellisia. Yhtä -iA-nimeä lukuun ottamatta (Pöyhiä) muut ovat -nen-nimiä (Halonen, Tähtinen). (-nen-nimiin palataan luvussa 6.1.)

Taulukko 4. Pirtinniemen sukunimien nimiesiintymien kielet ja rakennetyypit. Erilaisten sukunimien määrä on ilmoitettu suluissa.

\begin{tabular}{|l|r|r|r|r|r|r|r|r|}
\hline $\begin{array}{l}\text { PIRTINNIEMI } \\
\text { I (57) 72 }\end{array}$ & \multicolumn{2}{|c|}{ Suomea } & \multicolumn{2}{|c|}{$\begin{array}{l}\text { Ruotsia } \\
\text { kielinen }\end{array}$} & \multicolumn{2}{c|}{$\begin{array}{l}\text { Moni- } \\
\text { kielinen }\end{array}$} \\
\hline Johtimellinen & $(20)$ & 24 & - & & - & - & $(9)$ & 9 \\
\hline Kantasanatyyppinen & - & - & $(5)$ & 6 & $(2)$ & 5 & - & - \\
\hline Yhdyssanatyyppinen & - & - & $(16)$ & 20 & $(2)$ & 2 & $(1)$ & 3 \\
\hline Patronyyminen & - & - & $(2)$ & 3 & - & - & - & - \\
\hline Aviollinen kaksoisnimi & - & - & - & - & - & - & - & - \\
\hline Yht. & $(20)$ & 24 & $(23)$ & 29 & $(3)$ & 7 & $(11)$ & 12 \\
\hline \% & $(35,0)$ & 33,3 & $(40,4)$ & 40,3 & $(5,3)$ & 9,7 & $(19,3)$ & 16,7 \\
\hline
\end{tabular}


Ruotsinkieliset nimet ovat kantasanatyyppisiä (Storm), yhdyssanatyyppisiä (Wasastjerna) ja patronyymisiä (Karlsson). Yhdyssanatyyppisiä nimiä on eniten, ja ne ovatkin suomenruotsalaisessa nimistössä yleisiä (Blomqvist 1993, 188). Muunkieliset nimet hahmottuvat kaikki saksankielisiksi. Esiintymät jakautuvat kantasana- (Gerdt, Wahl) ja yhdyssanatyyppisiin (Seseman, Durchman). Wahl- ja Seseman-sukujen edustajat kuuluivat 180o-luvulla Varkauden teollisuuden omistajiin, ja molempien nimien kantajat olivat viipurinsaksalaisten kauppiassukujen jälkeläisiä (Hoffman-Hellsten 1997, Talka 2009). Durchman ja Seseman on tulkittu nimien alkuosan kielen antaman vihjeen perusteella saksankielisiksi, vaikka saksasta ruotsiin lainattu -mann-pääte (Blomqvist 1993, 155) on hautamuistomerkkeihin kirjattu päätteen ruotsinkielisen ortografian mukaisesti. Ortografia on ennen 1900-lukua usein horjuvaa, mistä kertoo myös se, että seurakunnan vainajarekisterissä kirjoitusasu on erilainen (Sesemann). Mahdollista on myös, että maisemaan on taltioitunut kirjurin virhe (ks. myös Kolehmainen, tulossa).

Monikieliset nimet ovat johtimellisia ja yhdyssanatyyppisiä oppineistonimiä. Johtimellisiin lukeutuu esimerkiksi Antell, jossa on useampikin historiallinen kerrostuma. Nimi palautuu suomenkieliseen paikannimeen Anttila, josta on muodostettu latinan -(i)us-johtimella sukunimi Anthelius. Kun ranska 1700-luvulla tuli latinan rinnalle kulttuurikieleksi, nimen johdin vaihdettiin ranskan -ell-ainekseen. (Blomqvist 1993, 151; 2006, 83.) Yhdyssanatyyppinen monikielinen nimi puolestaan on Wilkman, joka todennäköisesti palautuu paikannimeen (<Vilkkilä) (ks. Ylioppilasmatrikkeli 1640-1852, s.v. Wilkman).

\subsection{Ala-Kankku}

Taulukosta 5 käy ilmi, että nuorempi Ala-Kankun hautausmaa muodostaa erilaisen kielimaiseman. Sukunimiä on paljon, ja vainajia on haudattu paljon enemmän kuin Pirtinniemeen. Toisin kuin Pirtinniemessä Ala-Kankun maisemassa dominoivat suomenkieliset sukunimet.

Taulukko 5. Ala-Kankun hautausmaan sukunimien nimiesiintymien kielet ja rakennetyypit. Luvut suluissa ilmoittavat erilaisten sukunimien määrän.

\begin{tabular}{|l|r|r|r|r|r|r|r|r|}
\hline $\begin{array}{l}\text { ALA-KANKKU } \\
\text { I (221) 528 }\end{array}$ & \multicolumn{2}{|l|}{ Suomea } & \multicolumn{2}{|c|}{ Ruotsia } & \multicolumn{2}{c|}{$\begin{array}{l}\text { Muun- } \\
\text { kielinen }\end{array}$} & \multicolumn{2}{l|}{$\begin{array}{l}\text { Moni- } \\
\text { kielinen }\end{array}$} \\
\hline Johtimellinen & $(150)$ & 394 & - & - & $(1)$ & 1 & $(5)$ & 7 \\
\hline Kantasanatyyppinen & $(21)$ & 39 & $(3)$ & 3 & $(1)$ & 1 & - & - \\
\hline Yhdyssanatyyppinen & $(11)$ & 21 & $(22)$ & 49 & $(2)$ & 5 & - & - \\
\hline Patronyyminen & - & - & $(4)$ & 7 & - & - & - & - \\
\hline Aviollinen kaksoisnimi & $(1)$ & 1 & - & - & - & - & - & - \\
\hline Yht. & $(183)$ & 455 & $(29)$ & 59 & $(4)$ & 7 & $(5)$ & 7 \\
\hline \% & $\mathbf{( 8 2 , 8 )}$ & $\mathbf{8 6 , 5}$ & $(\mathbf{1 3 , 1})$ & $\mathbf{1 0 , 8}$ & $(\mathbf{1 , 8})$ & $\mathbf{1 , 3}$ & $(\mathbf{2 , 3})$ & $\mathbf{1 , 3}$ \\
\hline
\end{tabular}


Suomenkielisessä sukunimimaisemassa johtimelliset sukunimet muodostavat enemmistön. Taulukko 6 havainnollistaa niiden piirteitä. Niitä on yhteensä 394, joista erilaisia johtimellisia sukunimiä on 150. Samoin kuin Pirtinniemessä Ala-Kankussakin -nen-nimet nousevat aineistosta selvästi esiin. Erilaisia -nen-nimiä on 133, joiden esiintymiä on yhteensä 367. Muut suomenkieliset johdinainekset - Suomessa muuten yleinen -lA (Ahola, Taanila) sekä harvinaisemmat johdinainekset, kuten - $i A,-k k A,-k k O,-m O$ ja $-s t O$ (Patrikka, Liukko, Kannisto) (ks. Paikkala \& Paikkala 2000, 35-36) - eivät esiinny Ala-Kankun maisemassa taajaan.

Taulukko 6. Johtimellisten suomenkielisten sukunimien nimiesiintymien ja erilaisten nimien (suluissa) määrät johdinaineksittain Ala-Kankun hautausmaalla.

\begin{tabular}{|l|l|l|l|}
\hline ALA-KANKKU & \multicolumn{2}{|l|}{ sukunimet } & $\%$ \\
\hline$-n e n$ & $(133)$ & 367 & 93 \\
\hline$-l A$ & $(11)$ & 19 & 5 \\
\hline muut johdinainekset: $-j A,-k k A, k k O,-m O,-s t O$ & $(6)$ & 8 & 2 \\
\hline Yhteensä & $(150)$ & 394 & 100 \\
\hline
\end{tabular}

Johtimellisten nimien joukosta on mainittava erikseen Lumiala, joka on käännetty ruotsinkielisestä Lundson-nimestä (Grönstrand 2001, 69). Käännetyt nimet erottuvat maisemasta silloin, kun vanha ja uusi nimi sijaitsevat samassa hautamuistomerkissä, sukuhaudan eri hautamuistomerkeissä tai lähekkäisissä hautamuistomerkeissä. Muutoin käännetyt nimet sulautuvat nimimaisemaan, ja niiden historiaan liittyvää monikielisyyttä on vaikea havaita. Käännösnimet liittyvät kansalliseen heräämiseen ja suomalaisuusaatteeseen, joiden takia lukuisat ei-suomenkielisen nimen kantajat vaihtoivat nimensä suomenkieliseen 1800-luvun lopun ja 1900-luvun nimenmuuttokampanjoissa. Ala-Kankkuun haudatun Eino Antero (Lundson) Lumialan ja hänen puolisonsa Tyyne Johannan tapaan nimiä käännettiin kansallisen heräämisen jälkeenkin vielä 1920-luvulla (Suomen virallinen lehti 1928, 1). Suomenkielisiä nimiä ottivat suomenkielisten lisäksi ruotsinkieliset. Samassa prosessissa myös suomenkielisiä nimiä vaihdettiin. Uudet käännetyt nimet olivat usein tarkkoja tai likimaisia käännöksiä tai alkuperäisen nimen äänteellisiä mukaelmia, kuten Lumiala. (Närhi 1972, 50-52, 55-56; ks. myös Paikkala 2004.)

Taulukon 5 mukaan suomenkielisiä kantasana- ja yhdyssanatyyppisiä nimiä on johtimellisia nimiä huomattavasti vähemmän. Kantasanatyyppisten nimien joukkoon kuuluu eri aikoina syntyneitä, eri tavoin motivoituneita ja alun perin erilaisiin tarkoitteisiin tai ominaisuuden piirteisiin viittaavia nimiä (esim. Hotti, Tapio, Pasuri, Kokki, Mömmö, Kääpä). Osa kantasanatyyppisistä nimistä on varta vasten sukunimiksi muodostettuja nimiä ja sisältää luontosanastoa (esim. Aalto, Koski, Kuusi, Lahti, Laine, Lehti). Tällaisia sukunimiä otettiin erityisesti 1800-luvun lopussa ja 1900-luvun alussa. Yhdyssanatyyppiset sukunimet taas pohjautuvat usein luonto- tai asutusnimiin (Karikoski, Saloniemi, Talvenheimo). (Nimien taustoista ks. Mikkonen-Paikkala 2000.) 
Ala-Kankussa esiintyy aineiston ainoa aviollinen kaksoisnimi, Helve-Hirvonen. Nimi on vuonna 2005 kuolleen henkilön hautamuistomerkissä ja havainnollistaa siten tutkitun maiseman jähmettyneisyyttä: Ala-Kankkuun ei juurikaan enää myönnetä uusia hautapaikkoja, joten hautausmaan nimistö heijastaa vain rajallisesti viimeaikaisia nimistön ilmiöitä. Kaksoisnimien suosio on kasvanut 1970-luvulta lähtien (Paikkala 2012), mutta tämä kehitys ei ole jättänyt jälkiä Varkauden tutkituille hautausmaille.

Ruotsinkieliset nimet ovat kantasana- ja yhdyssanatyyppisiä sekä patronyymisiä nimiä. Kantasanatyyppisiin nimiin lukeutuu sotilasnimiä (Kanon), joita muodostettiin 1600-luvun lopulta lähtien ruotujakolaitoksessa, ja aatelisnimiä (Spåre) (Blomqvist 1993, 139, 160-169). Yhdyssanatyyppisiä nimiä on kantasanatyyppisiä nimiä enemmän. Varkauden ruotsinkieliset yhdyssanatyyppiset nimet ovat Suomessa yleisiä nimiä, joiden jälkiosat kuuluvat suomenruotsalaisen nimistön yleisimpiin jälkiosiin (esim. -berg, -gren, -man, -näs, -qvist, -sten, -ström) (Blomqvist 1993, 193-194). Patronyymisiä -son-päätteisiä nimiä ovat esimerkiksi Henriksson ja Johansson.

Vaikka Ala-Kankku on Pirtinniemeä paljon suurempi hautausmaa, muun- ja monikielisten sukunimien määrä on lähes sama. Kaikki muunkieliset sukunimet ovat saksankielisiä. Niihin lukeutuu kantasanatyyppinen Boucht, jonka ortografia on Helénin mukaan (1993, 8-10) historiassa muuttunut (vrt. nykysaksan Bucht'lahti'). Heléniin (mts.) nojautuen tulkitsemme nimen saksankieliseksi, vaikka B(o)uchtien esi-isä onkin tullut Suomeen Hollannista. Yhdyssanatyyppisiä saksankielisiksi lukeutuvia nimiä ovat Mahrberg ja Sternberg, ja johtimellinen -er-tekijäjohtimen sisältävä nimi on Brummer. Monikieliset nimet ovat kaikki oppineistonimiä tai niiden mallin mukaan otettuja ja annettuja (esim. Kandelin, Rapell).

\subsection{Tyttönimet}

Hautausmaiden nimimaisemaluonne korostuu entisestään, kun mukaan huomioidaan vainajien tyttönimet. Tyttönimien ilmoittaminen Varkauden hautamuistomerkeissä on tavallista (ks. Kolehmainen, tulossa). Varkauden aineistossa niiden ilmoittaminen yleistyy, kun ajassa siirrytään kohti nykyaikaa (ks. luku 6.1). Maisemallisesti tyttönimet erottuvat sukunimistä: tyttönimet ovat usein pienemmällä kirjainkoolla, eikä niiden sijainti hautamuistomerkissä ole yhtä keskeinen. Vanhemmalla Pirtinniemen hautausmaalla tyttönimiä on vain viisi: yksi suomenkielinen, kolme ruotsinkielistä ja yksi monikielinen oppineistonimi. Ala-Kankun hautausmaalla tyttönimiä on yhteensä 142 ja erilaisia tyttönimiä on 117. Taulukko 7 havainnollistaa Ala-Kankun tyttönimiä. Pirtinniemen tyttönimistä ei ole taulukkoesitystä, koska niitä on niin vähän.

Ala-Kankun tyttönimimaisema muistuttaa pitkälti Ala-Kankun sukunimistöä (ks. taulukkoa 5 edellä). Myös tyttönimimaisemassa dominoivat suomenkieliset nimet, ja suurin osa suomenkielisistä tyttönimistä on johtimellisia nimiä. Johtimellisten suomenkielisten nimien joukossa -nen-nimet ovat yleisimpiä (yht. 91 nimiesiintymää, 68 erilaista nimeä), ja muut eli - $l A$ - ja -iO-loppuiset nimet ovat harvinaisempia (yht. 10 nimiesiintymää ja erilaista nimeä). 
Taulukko 7. Ala-Kankun hautausmaan tyttönimien kielet ja rakennetyypit. Erilaisten sukunimien määrä on ilmoitettu suluissa.

\begin{tabular}{|l|r|r|r|r|r|r|r|r|}
\hline $\begin{array}{l}\text { Ala-Kankku, tyttönimet } \\
\sum \text { (117) } \mathbf{1 4 2}\end{array}$ & \multicolumn{2}{|l|}{ Suomea } & \multicolumn{2}{|l|}{$\begin{array}{l}\text { Muun- } \\
\text { kielinen }\end{array}$} & \multicolumn{2}{|l|}{$\begin{array}{l}\text { Moni- } \\
\text { kielinen }\end{array}$} \\
\hline Johtimellinen & $(78)$ & 101 & - & - & - & - & $(6)$ & 9 \\
\hline Kantasanatyyppinen & $(15)$ & 16 & $(2)$ & 2 & $(1)$ & 1 & - & - \\
\hline Yhdyssanatyyppinen & $(7)$ & 7 & $(6)$ & 6 & $(1)$ & 1 & - & - \\
\hline Patronyyminen & - & - & $(1)$ & 1 & - & - & - & - \\
\hline Yht. & $(100)$ & 124 & $(9)$ & 9 & $(2)$ & 2 & $(6)$ & 9 \\
\hline$\%$ & $\mathbf{( 8 5 , 5 )}$ & $\mathbf{8 7 , 3}$ & $(\mathbf{7 , 7})$ & $\mathbf{4 , 9}$ & $(\mathbf{1 , 7})$ & $\mathbf{1 , 4}$ & $\mathbf{( 5 , 1 )}$ & $\mathbf{6 , 3}$ \\
\hline
\end{tabular}

Ruotsin-, muun- ja monikielisten tyttönimien suhteellinen osuus on pienempi kuin Ala-Kankun varsinaisessa sukunimistössä. Tyttönimet laajentavat kuitenkin tutkittujen hautausmaiden kieliskaalaa: aineistossa esiintyy yksi englanninkielinen kantasanatyyppinen tyttönimi (Vrigth), joka on taulukossa 7 luettu yhdessä saksankielisen tyttönimen kanssa (Sternberg) muunkielisten joukkoon. Monikieliset tyttönimet ovat kaikki klassisten kielten johdinaineksia hyödyntäviä oppineistonimiä (esim. Ålander).

\section{Maantieteelliset ja ajalliset kerrostumat hautausmaamaisemassa}

Edellinen luku 5 kuvaa Varkauden hautausmaiden monikielistä maisemaa ja erikielisten nimien osuutta maisemassa. Tässä luvussa tarkennamme maisemakuvausta tarkastelemalla ensin suomenkielisten nimien alueellista profilia (6.1). Sen jälkeen kuvaamme nimimaiseman ajallisia kerrostumia (6.2).

\subsection{Sukunimien alueellinen profili}

Suomenkieliset sukunimet ovat syntyneet ja kehittyneet alueellisesti eri aikoina ja jakautuneet varhain itäiseen sukunimipohjaiseen ja läntiseen talonnimipohjaiseen lisänimikäytäntöön (Paikkala 1988; 1995; Mikkonen-Paikkala 2000, 16-17, 27). Hautausmaiden suomenkielistä maisemanosaa on siten mahdollista lähestyä siitä näkökulmasta, mitä tiedetään sukunimien syntyhistoriasta ja nimien alkuperäisestä tai keskeisestä levinneisyysalueesta.

Tämä luku luo maisemallisen vaikutelman Varkauden hautausmaiden suomenkielisistä sukunimistä. Tutkimme, miltä Varkauden sukunimistö näyttää sukunimien alkuperäisen syntyalueen tai keskeisen levikkialueen valossa. Alueellisen profiilin analyysi perustuu Pirjo Mikkosen ja Sirkka Paikkalan (2000) Sukunimet-teokseen, joka on kattavin ja laajimpaan lähdeaineistoon perustuva esitys suomenkielisten sukunimien etymologiasta, taustasta ja levikkialueesta. Tarkastelu rajautuu suomenkielisiin nimiin, koska 
muiden kielten nimistä vastaavaa esitystä ei ole saatavilla. Nimen on katsottu edustavan tiettyä aluetta, kun alue tai sen osa mainitaan nimiartikkelissa.

Nimiartikkeleissa mainitaan esimerkkejä nimen esiintymistä vanhoissa asiakirjoissa, kuten kirkonkirjoissa ja veroluetteloissa. Nimiesimerkit on valittu "alueilta, joissa kukin nimi on syntynyt tai jäänyt pysyväksi sukunimeksi tai joka on nimen olennaista levikkialuetta" (Mikkonen-Paikkala 2000, 10). ${ }^{7}$ Huomioimme vain 1900-lukua varhaisempia levinneisyystietoja kahdesta syystä. Ensinnäkin 1900-luvun levinneisyystiedot puuttuvat suurimmasta osasta nimiartikkeleita. Toiseksi olemme kiinnostuneita nimenomaan sukunimien alkuperästä eli siitä, missä päin Suomea sukunimet ovat ensimmäisenä esiintyneet. Jotta kuvaus olisi helposti ymmärrettävä ilman Suomen nykyisten paikkakuntien historiallista tuntemusta, olemme yksinkertaistaneet nimien alkuperän kuvauksen karkean nykymaakuntajaon mukaisesti seuraaviin 13 levinneisyysalueeseen: ${ }^{8}$

• Häme (Kanta-Häme ja Päijät-Häme)

- Kainuu

- Karjala (Etelä-Karjala, PohjoisKarjala sekä Neuvostoliitolle luovutetut Kannaksen alueet)

- Keski-Suomi

- Kymenlaakso

- Lappi (sis. entisen Peräpohjolan alueen)
- Pirkanmaa

- Pohjanmaa (Etelä-Pohjanmaa, KeskiPohjanmaa ja Pohjanmaa)

- Pohjois-Pohjanmaa

- Satakunta

- Savo (Etelä-Savo ja Pohjois-Savo)

- Uusimaa

- Varsinais-Suomi

Pirtinniemen aineistossa erilaisia suomenkielisiä sukunimiä on 20, joista yhtä ei löydy Sukunimet-kirjasta, eli käsiteltäviä nimiä on yhteensä 19. Ala-Kankun aineistossa erilaisia suomenkielisiä sukunimiä on 183 , joista 18 on niin harvinaisia, että ne puuttuvat Sukunimet-kirjasta. Saman nimen eri kirjoitusasut, kuten Väisänen/Wäisänen, huomioidaan vain kerran, koska kyse ei ole eri nimistä vaan saman nimen ortografisesta vaihtelusta. (Maisemallisista syistä nämä nimet laskettiin luvussa 5 erikseen.) Tällaisia tapauksia on

7 Tällä perusteella olemme ottaneet nimen levikkiin mukaan myös sellaiset maakunnat, joiden alueelta on annettu nimiesimerkkejä, vaikka niitä ei olisi mainittu nimiartikkelin juoksevassa tekstissä. Jonkin verran teos antaa esimerkkejä myös eri pitäjien käräjillä syytettyjen nimistä. Näitä alueita ei kuitenkaan ole laskettu mukaan nimen levinneisyyteen, jos käräjät ovat ainoa maininta nimen esiintymisalueesta. Nimiartikkeleissa on tietoa myös nykyisten sukunimien tai niiden ainesten esiintymisestä talonnimissä ja paikannimistössä. Talonnimistä ei aina ole kehittynyt sukunimiä, ja paikannimistön etymologinen tausta voi poiketa sukunimien taustasta. Tämän vuoksi talon- ja paikannimissä esiintyvät ainekset on jätetty tarkastelun ulkopuolelle.

8 Tämän artikkelin luokittelussa entisen Rautalammin suurpitäjän nimiesimerkit on merkitty sekä Savon että Keski-Suomen maakunta-alueisiin, sillä vanhaan suurpitäjään on kuulunut nykyisen Rautalammin alueen lisäksi Keski-Suomen läänin itäosia ja Kuopion läänin länsiosia (Mikkonen-Paikkala 2010, 11). Samoin Ruovesi on nykyään Pirkanmaata, mutta historiallisesti pitäjä on kattanut myös nykyään Etelä-Pohjanmaahan ja Keski-Suomeen kuuluvia alueita (Tarmio ym. 1978, 9), joten Ruoveden esiintymät on laskettu mukaan kaikkiin kolmeen alueeseen. 
4. Ala-Kankun osalta on siten käsitelty yhteensä 162 sukunimeä. Tyttönimet jäivät tämän luvun analyyseistä pois.

Kuvio 1 kuvaa Pirtinniemen ja kuvio 2 Ala-Kankun eri sukunimien viittä suurinta perinteistä levikkialuetta. Luvut kuvioissa viittaavat sukunimien määrään, jotka ovat syntyneet kyseisessä maakunnassa tai joiden keskeistä levikkialuetta maakunta on. Ympyröiden koko heijastaa kuhunkin maakuntaan assosioituvien nimien määrää. Koska nimet kulkeutuvat kantajiensa mukana paikasta toiseen, samat nimet voivat esiintyä usean eri maakunnan alueella. Ympyröiden päällekkäiset alueet kuvaavat samojen nimien yhteisiä levikkialueita. Esimerkiksi Pirtinniemen 19 nimestä seitsemän nimeä ja Ala-Kankun 162 sukunimestä 71 nimeä esiintyy vanhastaan neljän tai useamman maakunnan alueella. Alueet, jotka eivät limity, kuvaavat niiden nimien määrää, jotka eivät ole yhteisiä maakunnille.

Molemmissa nimimaisemissa hallitsevat itäsuomalaiset nimet. Pirtinniemen nimistä Savossa syntyneitä, pysyväksi jääneitä tai muutoin tavallisesti esiintyneitä on 19, ja karjalainen tausta on näistä nimistä 18:1la. Ala-Kankussa vastaavat luvut ovat Karjalan osalta 131 ja Savon osalta 120 . Kuvioista 1 ja 2 käy ilmi, että sukunimillä on joitain alueellisia kytköksiä useisiin Suomen maakuntiin, mutta muihin maakuntiin identifioituvien nimien määrät jäävät selvästi itäsuomalaisista nimistä.

Nimimaiseman alueellista profiilia on mahdollista tarkentaa tarkastelemalla molemmille hautausmaille tyypillisiä -nen-nimiä. Niitä pidetään usein itäsuomalaisina, vaikka vain osa -nen-nimistä edustaa vanhaa itäsuomalaista -nen-nimien kerrostumaa, jonka

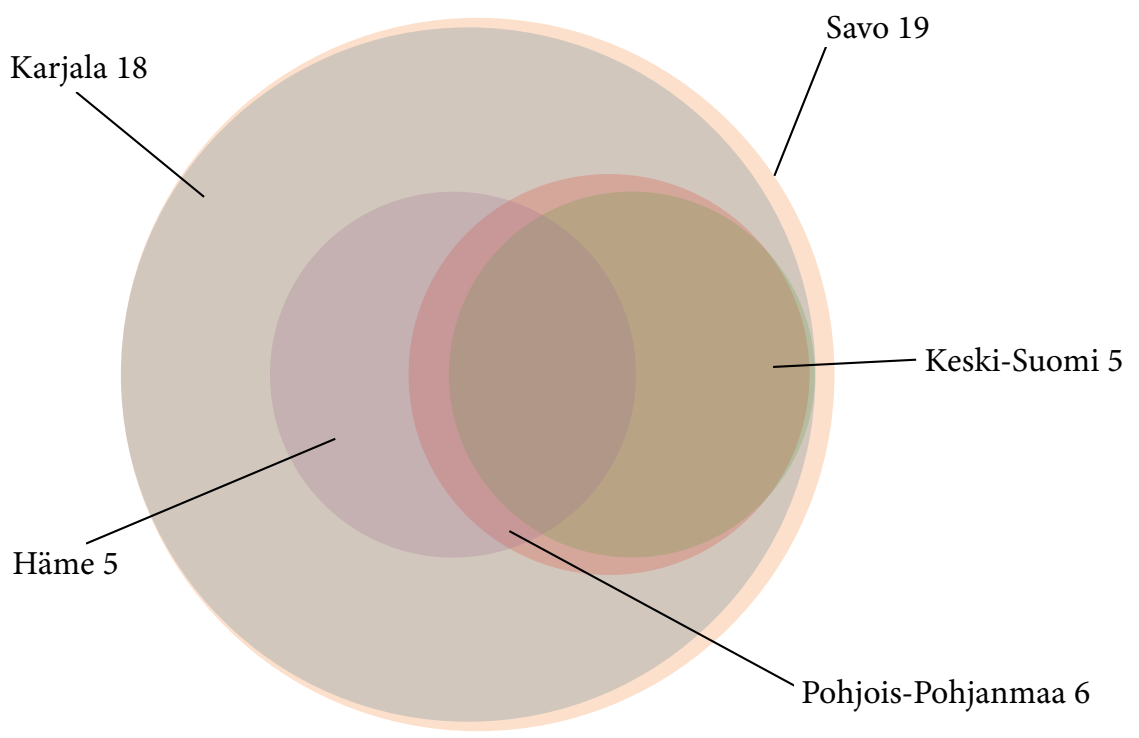

Kuvio 1. Pirtinniemen sukunimien viisi suurinta perinteistä levikkialuetta. 


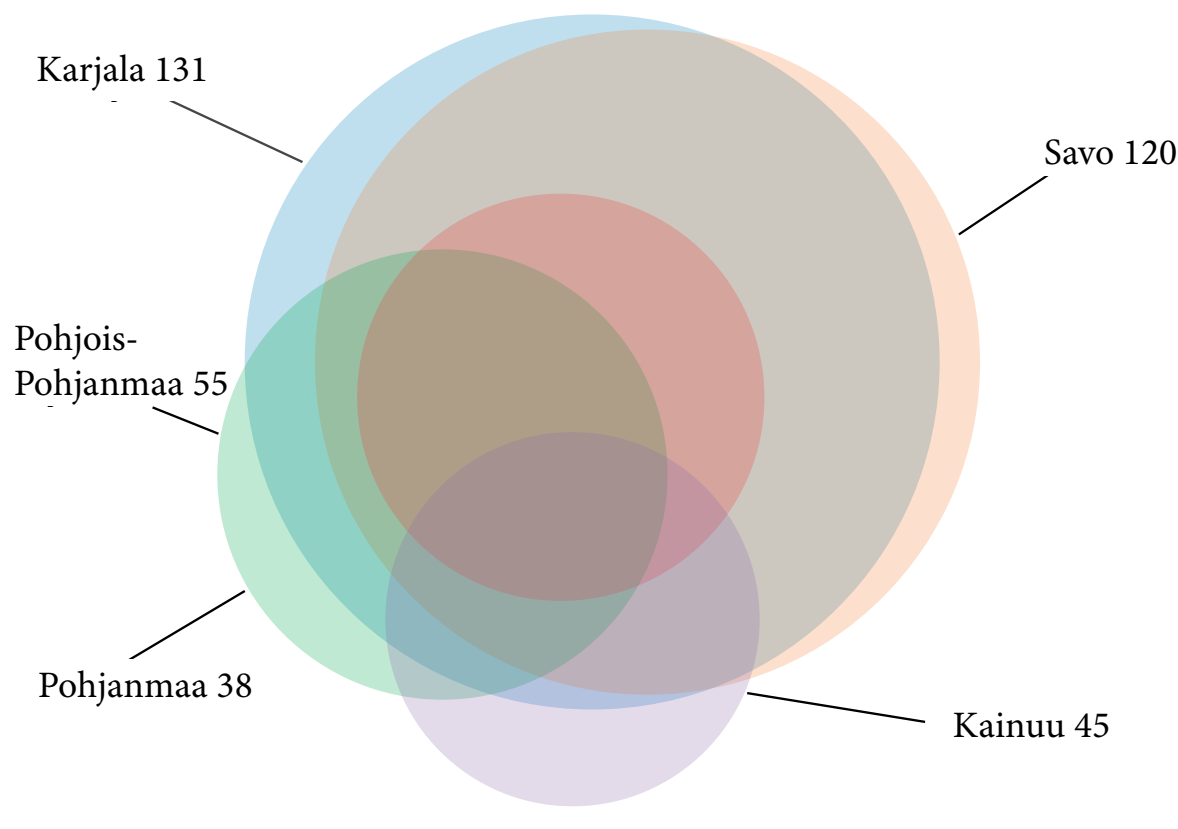

Kuvio 2. Ala-Kankun sukunimien viisi suurinta perinteistä levikkialuetta.

juuret palautuvat 1200-luvulle (Paikkala 1988, 2004). Länsisuomalaisella maalaisväestöllä sukunimijärjestelmää ei vanhastaan ollut, vaan vallalla oli talon- tai asutuksennimeen perustuva lisänimijärjestelmä, jossa nimi ei kuitenkaan ollut pysyvä eikä periytyvä. Länsi-Suomessa maalaisväestön sukunimijärjestelmä alkoi kehittyä 1850-luvulta alkaen, kun sukunimettömät länsisuomalaiset omaksuivat pysyvän periytyvän sukunimen. (Paikkala 1992; 1995; 2004; Mikkonen-Paikkala 2000, 16-17.) Uudet nimet olivat asuinpaikan nimiä (Alatalo, Matinolli, Ollila) tai luonto-, kasvisto-, maaperä- ja maastoappellatiiveista mallinmukaisesti muodostettuja nimiä. Luontosanan sisältäviä nimiä Paikkala (1992; 1995; 2004) luonnehtii Virtanen- ja Laine-tyypeiksi niiden yleisimpien edustajien mukaisesti (esim. Koskinen, Lehtonen, Virtanen - Aalto, Laakso, Laine). Tämä luontoaiheisten sukunimien kerrostuma liittyy kansalliseen heräämiseen.

Taulukko 8 havainnollistaa Varkauden -nen-nimiä. Myös niiden osalta maisema näyttää itäsuomalaiselta, sillä suurin osa Pirtinniemen ja Ala-Kankun -nen-nimistä kuuluu itäsuomalaiseen -nen-sukunimiperintöön eli sukunimi on alun perin syntynyt Itä-Suomessa tai sen keskeistä levinneisyysaluetta on Itä-Suomi. Itäsuomalaisiksi taulukossa 8 on luokiteltu -nen-nimet, jotka Kallion (1911, 12-13) mukaan ovat "ensi", "toisen" tai "kolmannen" luokan savolaissukujen sukunimiä tai jotka Matti Kuusen (1972) mukaan esiintyvät tyypillisemmin ja lukuisampina Itä- kuin Länsi-Suomessa eli ovat hänen luokituksessaan 
"varsinaisia" tai "osaksi" savolaisia sukunimiä. Itäsuomalaisiksi luetaan myös -nen-nimet, jotka eivät esiinny Kallion ja Kuusen tutkimuksissa, mutta joita Paikkala (2004) luonnehtii itäsuomalaisiksi. Vaihtoehtoisesti ne ovat Mikkosen ja Paikkalan (2000) mukaan joko syntyneet Savossa tai Karjalassa, jääneet näillä alueilla pysyviksi tai niiden keskeistä levikkialuetta ovat Savo tai Karjala. Tällaisia ovat Pirtinniemen hautausmaalla kaikki 19 erilaista nimeä. Ala-Kankussa erilaisia -nen-sukunimiä on 129. Niistä edellä mainittujen kriteereiden perusteella itäsuomalaisia on yhteensä 120 .

Taulukko 8. Erilaisten -nen-nimien profiili.

\begin{tabular}{|l|l|l|}
\hline & Pirtinniemi & Ala-Kankku \\
\hline Itäsuomalaisia -nen-nimiä & 19 & 120 \\
\hline Virtanen-tyypin -nen-nimi tai sen seurannaisnimi & - & 9 \\
\hline Yhteensä & 19 & 129 \\
\hline
\end{tabular}

Läntisiä luonto- ja maastoaiheisia Virtanen-tyypin -nen-nimiä on Varkauden hautausmailla vähän. Virtanen-tyyppi onkin levinnyt heikosti Savoon ja Pohjois-Karjalaan (Paikkala 2004, 388-389). Taulukossa 8 Virtanen-tyypin edustajiksi luokiteltiin kaikki ne -nennimet, jotka Kuusen (1972) itä- ja länsisuomalaisia -nen-nimiä vertailevan tutkimuksen mukaan ovat "epäsavolaisia" tai jotka Paikkala (2004) lukee Virtanen-tyyppiin tai sen seurannaisiin. Pirtinniemessä niitä ei ollut lainkaan. Ala-Kankun hautausmaalla tällaisia sukunimiä oli 9 (esim. Lehtonen, Pajunen ja Tähtinen). Vaikka Paikkala (2004) lukeekin nämä Varkauden 9 nimeä Virtanen-tyyppiin tai sen seurannaisiksi, havainnollistaa hän myös samojen nimien esiintymiä vanhoissa itäsuomalaisissa asiakirjoissa. Pääskynen- ja Tähtinen-nimiä lukuun ottamatta muiden Virtanen-tyyppisten nimien kohdalla ei voida siten sulkea pois sitä mahdollisuutta, että ne ovat Itä-Suomessa syntyneitä länsisuomalaisten samanasuisten nimien homonyymejä. Tämä mahdollisuus lisää -nen-nimimaiseman itäsuomalaista leimaa.

Taulukossa 8 suurin osa itäsuomalaisiksi määritellyistä -nen-nimistä vastaa muodostusmotiiviltaan tyypillisiä itäsuomalaisia -nen-nimiä. Ne perustuvat henkilönnimiin (Halonen), erilaisiin nimenkantajan ominaisuuksiin (Jalkanen), ammatti- tai säädynnimityksiin (Vartiainen, Herranen), heimo- tai syntyperään (Jääskeläinen) ja eläinten nimityksiin (Hukkanen). Monet näistä nimistä ovat vakiintuneet sukunimiksi liikanimistä. (Paikkala 1995.) Yksi nimistä on kansankielinen mukaelma ruotsinkielisestä nimestä (Taavitsainen < Davidsson). (Nimien taustoista ks. Mikkonen-Paikkala 2000.)

\subsection{Aikakerrostumia}

Tässä luvussa tarkastelemme ajallisia kerrostumia nimimaisemassa ja nykyaikaan säilyneitä muistoja eri aikakausilta. Kuviot 3, 4 ja 5 havainnollistavat Pirtinniemen ja AlaKankun hautamuistomerkeissä esiintyvien suku- ja tyttönimien kielten ajallista jakaumaa vainajien kuolinvuosien mukaisesti järjestettynä. Kaikissa hautamuistomerkeissä ei ole 
ilmoitettu vainajan elinvuosia. Tästä syystä nimiesiintymien määrä kuvioissa poikkeaa sukunimien kieliä havainnollistavista taulukoista 4, 5 ja 7 .

Pirtinniemen osalta 1800-luku on jaettu kahteen jaksoon kuviossa 3. Koska sen jälkeen haudattuja vainajia on vain vähän, on kuviossa yhdistetty 1900- ja 2000-luvut. Kuviosta käy ilmi, että eri ajoilta on säilynyt eri määrä hautamuistomerkkejä. Pylväät tuovat esiin maiseman muuttumisen: suomenkielisiä sukunimiä on säilynyt enemmän, kun ajassa edetään 1800-luvun loppua kohden. Ruotsinkielisiä sukunimiä taas on säilynyt vähemmän 1800-luvun lopulta kuin saman vuosisadan puolivälistä. Ruotsin-, muun- ja monikielisten sukunimien yhteenlaskettu osuus säilyy suurin piirtein samana tarkasteltuina 180o-luvun ajanjaksoina.

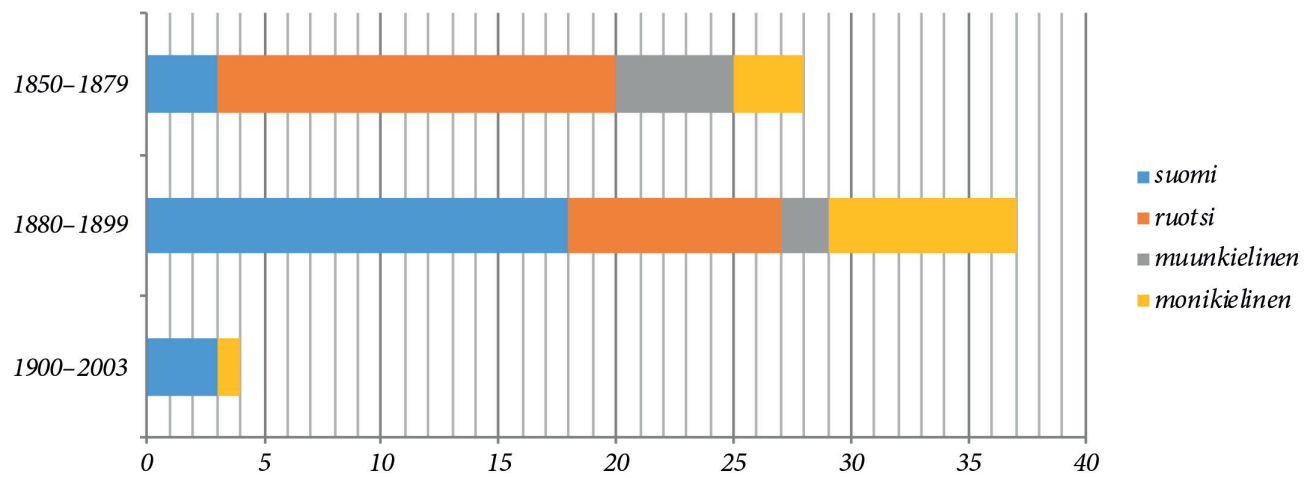

Kuvio 3. Pirtinniemen hautamuistomerkkien sukunimien (nimiesiintymiä yht. 71) kielellinen jakauma 1850-2003.

Ala-Kankun hautausmaan nimien ajallista jakautumista havainnollistaa kuvio 4, jossa nimiesiintymät on jaettu kaksikymmenvuosittaisiin ryhmiin. Kuviosta käy ilmi, että Ala-Kankussakin eri ajoilta on säilynyt eri määrä hautamuistomerkkejä. Suomenkieliset nimet hallitsevat Ala-Kankun maisemaa kaikkina ajanjaksoina. Lisäksi Ala-Kankunkin nimimaisemassa suomenkielisiä nimiä on säilynyt lähivuosikymmeniltä enemmän kuin hautausmaan historian alkuvuosikymmeniltä. Ruotsinkielisiä nimiä esiintyy erityisesti 180o-luvun lopun hautamuistomerkeissä, jonka jälkeen niiden esiintyminen muuttuu yksittäiseksi.

Ala-Kankun tyttönimien kieliä havainnollistaa kuvio 5, joka kuvaa tyttönimien yleistymistä maisemassa. Suomenkieliset tyttönimet muodostavat enemmistön koko tarkasteluajanjakson ajan 1890-2010, ja niiden määrä kasvaa kohti viimeisiä vuosikymmeniä 1990-2010. Samalla on kuitenkin muistettava, että myös hautamuistomerkkejä on AlaKankun hautausmaalla tuolta ajanjaksolta eniten. Ruotsin-, muun- ja monikielisten tyttönimien lukumäärät ovat tasaisen pienet koko tarkasteluajanjakson ajan. 


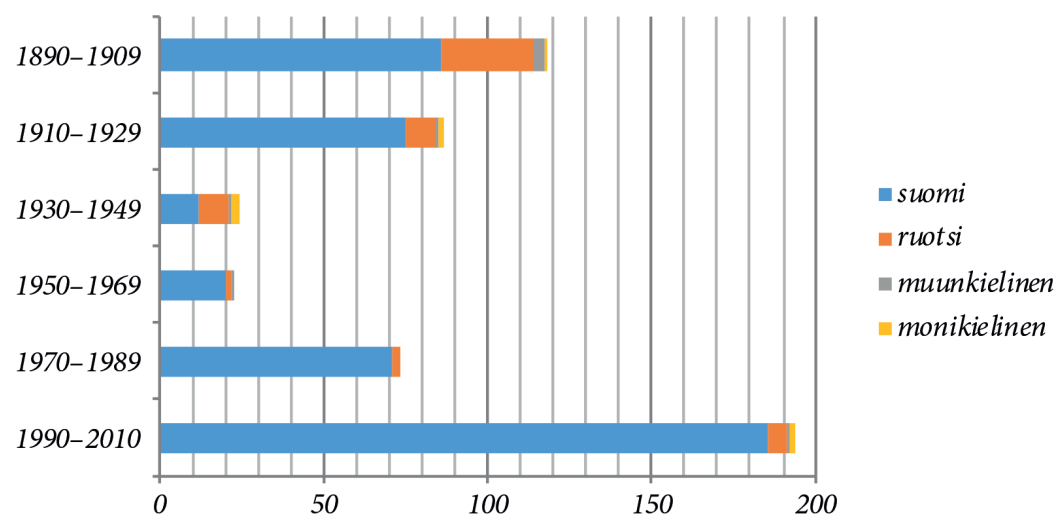

Kuvio 4. Ala-Kankun hautamuistomerkkien sukunimien (nimiesiintymiä yht. 519) kielellinen jakauma 1890-2010.

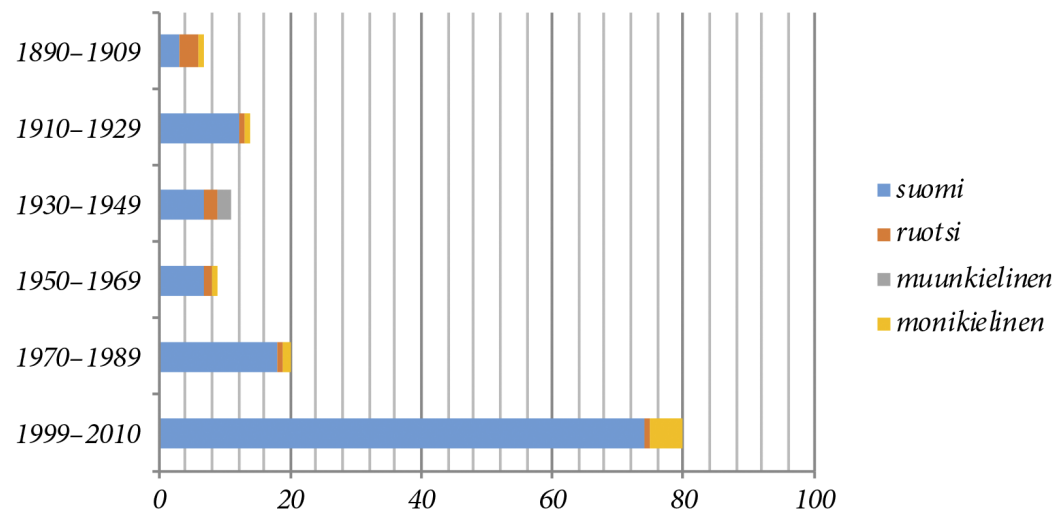

Kuvio 5. Ala-Kankun hautamuistomerkkien tyttönimien (nimiesiintymiä yht. 141) kielellinen jakauma 1890-2010.

Rakennetyyppien ajallinen jakauma mukailee rakennetyyppien yleistä jakaumaa, eikä tuo uusia näkökulmia. Pirtinniemen suomenkielinen sukunimistö koostuu ainoastaan johtimellisista nimistä, ja Ala-Kankun aineistossa johtimelliset nimet dominoivat kaikilta ajoilta säilyneissä hautamuistomerkeissä sekä varsinaisessa sukunimiaineistossa että tyttönimiaineistossa. 


\section{Kokoavaa tarkastelua}

Tässä artikkelissa katse kohdistui hautausmaihin, kulttuurihistoriallisesti tärkeisiin muistin ja muistamisen paikkoihin. Kielimaisemaltaan hautausmaat ovat erityisiä, sillä harva muu maisema sisältää yhtä paljon henkilönnimiä. Artikkelin tavoitteena on ollut kuvata Varkauden kahden vanhimman hautausmaan sukunimimaisemia ja pohtia, mitä nimet kertovat paikkakunnasta, sen historiasta ja sen kehitykseen vaikuttaneista ihmisistä. Varkauden tutkitut hautausmaat ovat sukunimiltään monikielisiä maisemia. Niissä näkyy suomen-, ruotsin-, saksan- ja englanninkielisiä sukunimiä sekä monikielisiä eri kielten aineksia yhdisteleviä nimiä.

Kielimaisemaa on usein lähestytty indikaattorina kieliyhteisön kielistä, kielten välisistä valta-asetelmista ja konflikteistakin. Hautausmaalla vainajien nimet muodostavat maiseman muista kirjoituksista poikkeavan osan, sillä sukunimien kielet eivät kerro vainajien kielistä, vaan ovat useiden muiden eri tekijöiden summa. Merkittävimmin monikielisyyttä Varkauden hautausmailla luo Suomessa vaikuttanut säätyjakoinen nimijärjestelmä, jonka tuotoksia hautausmailla esiintyvät suomen-, ruotsin- ja monikieliset nimet ovat. Suomalaiset sukunimet ovat kehittyneet osin areaalisesti itä- ja länsisuomalaisiin nimikäytänteisiin, osin suomenkieliseen ja suomenruotsalaiseen perintöön ja osin säädyittäin. Vanhimman sukunimikerroksen muodostaa itäsuomalainen sukunimistö, josta iso osa on erilaisia Varkauden hautausmailla runsaasti esiintyviä -nen-päätteisiä nimiä (esim. Koponen). Nuorempi suomenkielinen läntinen sukunimikerrostuma on jättänyt paljon vähemmän jälkiä Varkauden maisemaan (kuitenkin esim. Ahola, Taanila, Virtanen, Laine).

Vanhemmalla Pirtinniemen hautausmaalla ruotsinkielisiä (esim. Spåre, Kanon, Johansson, Bergström) nimiä on enemmän kuin suomenkielisiä. Nimet heijastavat 180o-luvulla perustettua ruukinseurakuntaa ja sen asutusta, jonka ulkopuolelle jäi teollisuuden työväestön asuinalue. Työläisten asuinalueen lähistölle perustetulla Ala-Kankun hautausmaalla puolestaan suomenkieliset nimet dominoivat. Suomen- ja ruotsinkielisten nimien varjoon Varkaudessa jää monikielinen, ruotsista, suomesta, klassisista kielistä ja ranskasta ammentava ja niitä keskenään sekoittava oppineistonimistö ja sen mallin mukainen sukunimistö (esim. Antell, Wilkman). Tämä monikielinen nimistö on ollut käytössä koko maassa sekä suomen- että ruotsinkielisellä väestönosalla.

Sukunimimaiseman monikielisyys on myös muuttoliikkeen aikaansaannos. Varkaudessa erityisesti saksan- ja englanninkieliset nimet kertovat muuttoliikkeestä ja viittaavat henkilön, hänen perheensä tai sukunsa toisessa kulttuurissa sijaitsevaan alkuperään (esim. Seseman, Wahl, Vright). Osa näistä nimistä ei ole välttämättä tullut Suomeen Varkauteen haudattujen nimenkantajien mukana, vaan jo kauan sitten (esim. Vrigth). RuotsiSuomessa saksankieliset nimet ja nimiainekset ovat osin sulautuneet ruotsiin ja tulleet osaksi myös suomenruotsalaista nimistöä.

Muuttoliike ei vaikuta ainoastaan nimimaiseman monikielisyyteen, vaan myös siihen, millaisia maisemassa näkyvät suomenkieliset nimet ovat. Varkaudessa molemmat 
hautausmaat näyttävät itäsuomalaisilta maisemilta. Pääosa suomenkielisistä nimistä on joko syntynyt Itä-Suomessa tai niiden tyypillistä levikkialuetta on Itä-Suomi. Molemmilla hautausmailla -nen-nimiä on paljon. Nimet välittävät siten kuvaa nimenkantajien ja heidän perheittensä itäsuomalaisesta taustasta ja eri aikoina Suomen sisältä Varkauteen suuntautuneesta muuttoliikkeestä.

Monikielisyys on osin piilossa nimimaisemassa. Osa maiseman suomenkielisistä nimistä on käännösprosessin tuloksia tai nimiä, joita erityisesti 1900-luvun alussa otettiin ruotsinkielisen nimen tilalle merkkinä identifioitumisesta suomenkieliseen kulttuuriin. Varkaudessa esimerkiksi Lumiala- ja Lundson-nimiä kantavat lähekkäiset hautamuistomerkit paljastavat ohikulkijoille nimimaisemaan kätkeytynyttä käännettyyttä sekä käännettyjen ja mukaillen tuotettujen uusin nimien taakse kätkeytyneitä kieliä.

Hautausmaa on ajallisesti kerrostunut maisema, jonka sukunimet ovat eri vuosisadoilla ja vuosikymmeninä kuolleiden vainajien nimiä. Varkaudessa nimimaisema suomenkielistyy, kun liikutaan ajassa kohti nykyisyyttä. Ruotsinkielisiä nimiä on molemmilla hautausmailla säilynyt erityisesti 180o-luvulla kuolleiden hautamuistomerkeissä. Sen jälkeen ne alkavat vähentyä ja antaa tilaa suomenkielisille nimille. Muun- ja monikielisiä nimiä on kaikkina aikoina ollut vähän.

Kertooko hautausmaiden sukunimimaisemien suomenkielistyminen yleisestä kehityksestä suomalaisten sukunimistössä, joka alkoi suomenkielistyä 1850-luvulta alkaen? Yhtäältä suomenkielisiä sukunimiä tuli merkittävästi lisää, kun länsisuomalainen rahvas, jolla ei aiemmin ollut ollut suvussa periytyvää sukunimeä, omaksui pysyvän suomenkielisen sukunimen. Toisaalta lukuisat henkilöt vaihtoivat ei-suomenkielisen sukunimensä tilalle uuden suomenkielisen sukunimen (Närhi 1972, 51-52; Paikkala 2004, 418-422). Varkauden maisemassa dominoivat kuitenkin profiililtaan itäsuomalaiset nimet, eivätkä länsisuomalaiset otetut nimet, joten suomenkielisen sukunimistön yleinen suomenkielistyminen on vaikuttanut Varkauden maisemaan vain vähän.

Maiseman suomenkielistyminen heijastaakin ennen kaikkea hautausmaille haudattujen henkilöiden profiilia ja niitä hautamuistomerkkejä, jotka eri ajoilta ovat säilyneet nykypäivään, ja suomenkielistymiselle on vaikea antaa muita selityksiä ilman väestöhistoriallista tutkimusta. Mahdollisia vaikuttaneita seikkoja voivat olla tehtaiden työväen määrän kasvu ja säätyläispohjaisen ammattiväen osuuden väheneminen sekä tavallisen kansan kasvava rekrytointi tehtaiden, hallinnon ja kaupan palvelukseen. Kaikki Varkauteen muuttaneet eivät edes ole jättäneet jälkiä hautausmaamaisemaan. Esimerkiksi kielitilastoissa näkyy ruotsinkielisten 1960-luvulla alkanut massamuutto Varkaudesta (ks. luku 4). Näiden henkilöiden nimet eivät näy Varkauden maisemassa.

Osin Varkauden hautausmaat vaikuttavat ajassa pysähtyneiltä maisemilta, joihin ei ole taltioitunut jälkiä suomalaisen nimistön uusimmasta kehityksestä. Koska Pirtinniemeen ja Ala-Kankkuun ei enää juurikaan myönnetä uusia hautapaikkoja, maisemasta puuttuvat esimerkiksi aviolliset kaksoisnimet miltei kokonaan.

Yhteenvetona voidaan todeta, että Varkauden hautausmaiden hautamuistomerkkeihin tallentunut monikielinen sukunimimaisema on monimutkainen yhtälö: se heijastaa 
paikkakunnan itäistä sijaintia, on Suomessa vaikuttaneen säätyjakoisen nimijärjestelmän aikaansaannos, sitä on muovannut paikkakunnalle suuntautunut muuttoliike Suomesta ja muualta ja siihen on vaikuttanut kääntäminen. Se on ajallisesti kerrostunut maisema, jossa vanhimpien säilyneiden hautamuistomerkkien nimissä on enemmän monikielisyyttä: enemmän ei-suomenkielisiä, ruotsinkielisiä, muunkielisiä ja monikielisiä oppineisto- ja niiden mallin mukaisia nimiä.

Näkökulma tässä artikkelissa on ollut synkroninen, maisemassa liikkuvan hautausmaavierailijan näkökulma. Kokonaan toisenlaisen lähestymisen maisemaan muodostaisi sukunimien etymologinen tarkastelu, jonka kautta olisi mahdollista nostaa esiin esimerkiksi suomenkielisten nimien taakse kätkeytyvää historiallista monikielisyyttä ja eri aikoina tapahtuneita kielikontakteja (esim. Ala-Kankun Nissinen < Nikolaus ja Koponen $<$ Prokopi, ks. Mikkonen-Paikkala 2000). Vaihtoehtoja tarjoavat muut aineistot ja lähestymistavat, kuten kirkonkirjat tai sukututkimuksen menetelmät, jotka ovat kuitenkin yhteisön jäsenten kokemuksen ulkopuolella toisin kuin nykyaikaan säilynyt hautausmaakielimaisema. Se, miten varkautelaiset tavalliset kielenpuhujat kokevat hautausmaiden sukunimimaiseman ja miten he tulkitsevat nimiä, muodostaisikin tärkeän tutkimuskysymyksen, joka rajautui kuitenkin tämän artikkelin ulkopuolelle. Mielenkiintoista olisi tutkia myös sitä, millaisen kokonaisuuden hautamuistomerkkeihin kaiverretut sukunimet muodostavat muiden erikielisten kirjoitusten (esim. muistovärssyt, ammatit) kanssa sekä millaisia mahdollisesti monikielisiä etu- ja sukunimien yhdistelmiä esiintyy ja miksi. Kaupallisten nimien osalta kielimaisema- ja nimistöntutkimuksen näkökulmien yhdistämisen mahdollisuuksia korostaa Guy Puzey (2016). Nähdäksemme kielimaisematutkimus mahdollistaa uudenlaisen lähestymisen myös maisemassa näkyviin henkilönnimiin suomalaisessa yhteiskunnassa, joka parhaillaan monikulttuuristuu ja monikielistyy ennen näkemättömällä tavalla.

\section{Lähteet}

\section{Aineslähteet}

1442 hautamuistomerkkien valokuvaa Varkauden evankelis-luterilaiselta seurakunnalta.

\section{Kirjallisuus}

Ainiala, Terhi - Saarelma, Minna - Sjöblom, Paula 2008: Nimistöntutkimuksen perusteet. SKS, Helsinki.

Alanen, Mirka 2012: Kieliresurssit ja niiden väliset suhteet Pajalan ja Pykeijän kielimaisemissa. Pro gradu -tutkielma. Kielten laitos. Jyväskylän yliopisto. Saatavissa: https://jyx.jyu.fi/handle/123456789/40765 [viitattu 7.1.2017].

Backhaus, Peter 2007: Linguistic landscapes. A comparative study of urban multilingualism in Tokyo. Multilingual Matters, Clevedon, Buffalo ja Toronto. https://doi.org/10.21832/9781853599484

BlomQvist, Marianne 1993: Personnamnsboken. Finn Lectura, Helsinki.

- 2006: Vad heter finlandssvenskarna? Svenska folkskolans vänner, Helsingfors.

Eckert, Eva 1998: Language and ethnicity maintenance: Evidence of Czech tombstone inscriptions. 
Markers 15, 204-234.

Edelman, Loulou 2009: What's in a name? Classification of proper names by language. Elana SHOHAmy ja Durk Gorter (toim.): Linguistic landscape. Expanding the scenery, 141-154. Routledge, New York ja Lontoo. https://doi.org/10.4324/9780203930960

2010: Linguistic landscapes in the Netherlands. A study of multilingualism in Amsterdam and Friesland. Väitöskirja, Amsterdamin yliopiston kielitieteen laitos. Saatavissa https://www.lotpublications.nl/Documents/261_fulltext.pdf [viitattu 3.3.2019].

Graves, Thomas E. 1983: Liebster Kinder und Verwandten: Death and ethnicity. Keystone folklore 2: $1-2,6-14$.

- 1988. Pennsylvania German gravestones: An introduction. Markers V, 60-95.

GrÖNSTRAND, LeA 2001: Leppävirran Lundson/Lumiala-suku. Torniosta Leppävirralle 1823. Sukuhistoriaa vuosilta 1786-2001. Oy Edita Ab [s.l.].

Helén, Pauli 1993: Veronkantokirjuri Gabriel Buchtin jälkeläiset. Tuisku Camenaeus -sukuseura, Helsinki.

Hoffman, Kai - Hellsten, Tanja 1997: Wahl, Paul. Kansallisbiografia. Studia Biographica 4. SKS, Helsinki.

ITKONEN, HANNU 2004: Varkautelaisten vuosisata. SKS, Helsinki.

Kallio, O. A. 1911: Savolaisia sukuja ja sukunimiä. Kansanvalistusseura, Kansanvalistusseuran kotiseutukuvauksia n:o 14. Helsinki.

Kiviniemi, Eero - Pitkänen, Ritva Lissa - Zilliacus, Kurt 1974: Nimistöntutkimuksen terminologia. Terminologin inom namnforskningen. Castrenianumin toimitteita 7. Helsingin yliopisto, Helsinki.

Kolehmainen, LeEna tulossa: Menneen monikielisyyden jälkiä nykyisyydessä: Varkauden hautausmaiden kielimaisemaa. Julkaistavaksi lähetetty artikkelikäsikirjoitus.

Kotilainen, SEIJA 2015: Suullinen tiedonanto 17.12.2015.

KuUsi, MatTi 1972: Savolaissuvuista. Kalevalaseuran vuosikirja 52, 99-115.

Laki sukunimestä N:o 328/1920. Saatavissa https://www.genealogia.fi/nimet/nimio328s.htm [viitattu 3.6.2019].

LANDry, Rodrigue - Bourhis, Richard Y. 1997: Linguistic landscape and ethnolinguistic vitality. An empirical study. Journal of Language and Social Psychology 16: 1, 23-49.

https://doi.org/10.1177/0261927X970161002

Mikkonen, Pirjo - Paikkala, Sirkka 200o: Sukunimet. Uudistettu laitos. Otava, Helsinki.

MODÉER, IVAR 1989: Svenska personnamn. Anthroponymica Suecana 5. Studentlitteratur, Lund.

Nevala, Arto 2003: Vuosisata varkautelaista työväenjärjestötoimintaa: agitatsioonia, vaikuttamista ja yhteistyötä. Varkauden työväenliikkeen historiatoimikunta, Varkaus.

NÄrHI, EeVA MARIA 1972: Ei susikaan sukunimestään suutu. Katsaus suomalaisten sukunimiin. Kalevalaseuran vuosikirja 52, 41-63.

Ollikainen, Sirpa - Peiponen, Irma - Solmu, Heli 1979: Varkauden historiikki. [S.l., ei kustantajaa.]

Paikkala, SirkKa 1992: Länsisuomalaisista sukunimistä. Sukutieto 1, 4-8. Saatavissa https://www.genealogia.fi/nimet/nimi21s.htm [viitattu 31.7.2018].

1995: Från olika namnsystem till ett enhetligt släktnamnssystem i Finland. NORNA-rapporter 58, 109-127. Saatavissa https://www.genealogia.fi/nimet/nimi31r.htm [viitattu 31.7.2018]. 1988: Finnische Familiennamen auf -(i)nen. Studia Anthroponymica Scandinavica 8/1988, 27-69. 2004: Se tavallinen Virtanen: suomalaisen sukunimikäytännön modernisoituminen 1850-luvulta vuoteen 1921. SKS, Helsinki.

2012: Puolison nimi vai oma nimi? Kielikello 1/2012. Saatavissa https://www.kielikello.fi/-/ puolison-nimi-vai-oma-nimi- [viitattu 15.8.2018].

Paikkala, Sirkka - Paikkala, Jarmo 2000: Tilastotietoja suomalaisten sukunimistä 1998. Pirjo MikKONEn ja SirkKa PaikKala (toim.): Sukunimet, 31-45. Uudistettu laitos. Otava, Helsinki.

PUZeY, GUy 2011: Signscapes and minority languages. Language conflict on the street. ElISHA Foust ja Sophie FugGle (toim.): Word on the street, 33-51. Institute of Germanic and Romance Studies, London. 
Puzey, Guy 2016: Linguistic landscapes. CArole Hough (toim.): Oxford handbook of names and naming, 395-411. Oxford University Press, Oxford.

SaArelma-Paukkala, Minna 2017: Etunimikirja. Suomalaiset nimitrendit 20oo-luvulla. SKS, Helsinki.

Seibicke, Wilfried 2008: Die Personennamen im Deutschen: Eine Einführung. De Gruyter, Berliini \& Boston. https://doi.org/10.1515/9783110973228

Sృ̈̈вlom, Paula 2006: Toiminimen toimenkuva. Suomalaisen yritysnimistön rakenne ja funktiot. Suomalaisen Kirjallisuuden Seuran Toimituksia 1064. SKS, Helsinki.

SOIKKANEN, Hannu 1963: Varkauden historia. Helsinki.

SPOLSKy, Bernard 2009: Prolegomena to a sociolinguistic theory of public signage. Elana Shohamy ja Durk Gorter (toim.): Linguistic landscape. Expanding the scenery, 25-39. Routledge, New York. https://doi.org/10.4324/9780203930960

SKS = Suomalaisen Kirjallisuuden Seura

Suomenmaan tilastollinen vuosikirja 1879. Tilastollinen toimisto, Helsinki.

Suomen tilastollinen vuosikirja 1910-1972. Tilastollinen päätoimisto, Helsinki.

Suomen virallinen lehti 1928. Nro 1, 2.1.1928.

SYRJÄLÄ, VÄINÖ 2016: Namn i gatubilden - om namn i Svenskfinlands lingvistiska landskap. NORNArapporter 93, 263-286. Saatavissa http://nors.ku.dk/publikationer/webpublikationer/nornarapporter-93/syrjala.pdf [viitattu 10.3.2018].

TALKA, ANU 2009: Kauppaneuvos Paul Wahl (1830-1875). Suomen talouselämän vaikuttajat. SKS, Helsinki.

Tamosiunaite, Aurelija 2012: In search of past identities: Lithuanian Chicago. Suullinen esitelmä. 19. Sociolinguistics Symposium, 21.-24.8. 2012, Freie Universität Berlin.

Tarmio, Hannu - Heinonen, Marketta - Korpela, Kalevi (toim.) 1978: Suomenmaa. Maantieteellis-yhteiskunnallinen tieto- ja hakuteos. Osa 7, Ruotsinpyhtää-Öja. WSOY, Porvoo.

TEgNÉR, EsAIAS 1930 [1882]: Om svenska familjenamn. [Ilmestynyt alun perin 1882 Nordisk tidskrift -lehdessä.] Esaias TegnéR: Ur språkens värld III. Fem uppsatser, 45-158. Albert Bonniers förlag, Stockholm.

Tilastokeskus 2017: Suomen tilastollinen vuosikirja. Tilastokeskus, Helsinki. Saatavissa https://www. stat.fi/tup/julkaisut/tiedostot/julkaisuluettelo/yyti_stv_201700_2017_17863_net.pdf [viitattu 23.7.2018].

2019: Tilastokeskuksen PX-Web-tietokannat. Väestö 31.12. Saatavissa http://pxnet2.stat. fi/PXWeb/pxweb/fi/StatFin/StatFin__vrm__vaerak/statfin_vaerak_pxt_031.px/table/ tableViewLayout $2 /$ ?rxid= $7 \mathrm{f}_{65} \mathrm{fd}_{71}-79 \mathrm{f}_{2}-43 \mathrm{~b} 5$-aeb9-5785 $\mathrm{b}_{3} 66 \mathrm{~b}_{3} 5 \mathrm{f}$ [viitattu 3.3.2019].

Tufi, Stefania - Robert Blackwood 2010: Trademarks in the linguistic landscape: methodological and theoretical challenges in qualifying brand names in the public space. International journal of multilingualism 7:3, 197-210. https://doi.org/10.1080/14790710903568417

Vainajarekisteri 2015: Pirtinniemi ja Ala-Kankku. Varkauden evankelis-luterilainen seurakunta.

VANDAM, KARA 2009: Dutch-American language shift: evidence from the grave. LACUS Forum XXXIV, 33-42.

Ylioppilasmatrikkeli 1640-1852: Verkkojulkaisu 2005. Saatavissa https://ylioppilasmatrikkeli.helsinki.fi [viitattu 6.6.2019]. 


\section{KukKa-MaAria Wessman and Leena Kolehmainen: Multilingualism and traces of past migration: temporal and linguistic layers in the linguistic namescapes of Varkaus}

This article examines the two oldest cemeteries in Varkaus, a small industrial town in eastern Finland, as linguistic landscapes. It focuses on the most visually dominating part of this landscape, specifically the personal names of the deceased on the gravestones. By combining onomastics with the study of linguistic landscapes, we can describe the cemetery namescape and investigate what the cemetery namescape reveals about past migration and multilingualism in the given locality. Varkaus cannot be characterised as a super-diverse community, but it has been described as "a melting pot on a Finnish scale" (Soikkanen 1963). This characterisation refers to labour migration to Varkaus caused by industrialisation, especially in the beginning of the $20^{\text {th }}$ century. Traces of this past multilingualism are still visible in the oldest cemeteries.

In previous studies on linguistic landscapes, proper names - personal names included - have turned out to be challenging, since their language is difficult to determine (Edelman 2009). Previous studies on cemetery linguistic landscapes have examined migration and its effects (Eckert 1998; Graves 1983; 1988; Pavlenko 2010; Piller 2016; Tamosiunaite 2012; VanDam 2007), but to our knowledge, the cemetery namescape has not been investigated. Our objective is to show that it is possible to analyse the languages in the namescape by using onomastic methods.

The data consist of 1,400 photographs of gravestones, showing 600 surnames and 147 maiden names. The photos were taken in 2009-2011. The names have been categorised into five groups according to the established classification of Finnish onomastics: root word, compound, derivational, patronym and hyphenated married surnames (see e.g. Paikkala-Paikkala 2000, 36-38).

The classification by language is based on linguistic landscape studies, and the language of the surnames is determined by their structural elements, such as suffixes. The cemetery landscapes from Varkaus in this study are multilingual. In addition to Finnish (Halonen, Kuusi, Lumiala) and Swedish (Karlsson, Wasastjerna) surnames, there are also German (Brummer, Seseman, Wahl) and English (Vright) surnames found on the gravestones. Linguistic diversity manifests also in multilingual intelligentsia names (Antell, Ålander), which combine elements from different languages.

The oldest cemeteries in Varkaus are frozen landscapes, because no new burial plots are available. Therefore, the newest trends in Finnish surnames, such as hyphenated married names, are not visible in the studied landscapes. There are less Finnish than Swedish, German, English and multilingual names in the older and smaller Pirtinniemi cemetery, while in Ala-Kankku, Finnish surnames dominate the landscape. Eastern Finnish derivational surnames with the suffix -nen (Koponen) are prominent in both landscapes. These cemeteries are also partly translated sceneries in which multilingualism remains hidden behind translated surnames.

The multilingualism of the namescape is mostly due to the inherent multilingualism in the Finnish and Finland Swedish personal name system. Moreover, the namescapes reflect the town's geographical location in eastern Finland and migration both from the surrounding region and from more distant areas. Thus, the cemetery linguistic landscape is not a direct copy of the linguistic resources of the speakers of its society, the deceased or their family members.

Kukka-Maaria Wessman kakwes@utu.fi Suomen kieli ja suomalais-ugrilainen kielentutkimus 20014 Turun yliopisto
Leena Kolehmainen leena.kolehmainen@utu.fi Saksan kieli 20014 Turun yliopisto 